KOHLER M., TANNIER C., BLOND N., AGUEJDAD R., CLAPPIER A. (2017), Impacts of several urban-sprawl countermeasures on building (space heating) energy demands and urban heat island intensities. A case study, Urban Climate, vol. 19, pp. 92-121.

\title{
Impacts of several urban-sprawl countermeasures on building (space heating) energy demands and urban heat island intensities.
}

\section{A case study of the Strasbourg-Kehl urban region, France-Germany}

\begin{abstract}
Controlling the urban development and protecting the natural habitats are major challenges for urban planners. With respect to these challenges, we assess the influence of different spatial planning policies on the urban heat island (UHI) intensity and the energy demand for building space heating in Strasbourg-Kehl urban region (France-Germany). For this purpose, the SLEUTH* urban growth model is coupled off-line with the WRF/urban climate modeling system in order to simulate the impacts of three types of urban development (compact, moderately compact, and sprawling development) combined with ecological preservation rules. Two additional software applications, Graphab and MorphoLim, are used to define the ecological and urban spatial structures, and drive the SLEUTH* simulations. The simulations for the year 2010 are consistent with the existing climate data (mean bias on temperatures less than or equal to $1^{\circ} \mathrm{C}$ ) and annual energy consumptions for building space heating estimated via a building typology energy assessment approach (discrepancies of 20\%). Simulated urban development scenarios for the year 2030 show slight effects on UHI intensities and heating energy demands in buildings. Those results suggest that urban sprawl countermeasures have no significant effect on the UHI intensity and building energy requirements when considering a moderate urban growth and realistic planning scenarios.
\end{abstract}

Keywords: residential development, ecological connectivity, urban heat island, urban climate modeling, building space heating

\section{Highlights}

- Building heating energy demand is simulated for several urban planning policies

- The dominant land cover approach cannot represent scattered urban patterns

- Realistic planning scenarios have little impact on building energy demands

- UHI intensities vary greatly depending on the chosen indicator 


\section{Introduction}

One of the major challenges facing urban and regional planners is to limit the negative effects of urban sprawl, especially the increasing number of journeys by car and the fragmentation of natural and agricultural land. Another major challenge is to reduce the energy consumption in buildings for space heating and cooling as well as the urban heat island (UHI) effect (i.e. the characteristic warmth of the atmosphere in urban areas as compared to their surroundings). These two planning challenges relate largely, although not exclusively, to the question of where to locate new urban developments. The long-standing debate about the most efficient (or virtuous) urban form often opposes compact cities to sprawling cities. Yet no consensus has been reached about the urban form that will best allow planners to achieve the objectives set out above. Moreover, it is difficult to transcribe planning objectives into quantitative indexes or land use land cover maps, which is a source of endless debate (Mallampalli et al., 2016).

Many studies have already reported that urban forms, in particular built density, residential parcel design, and the type and arrangement of vegetation all impact microclimates (Givoni, 1989; Bonan, 2000; Emmanuel and Fernando, 2007; Guhathakurta and Gober 2010; Hart and Sailor, 2009; Stone and Norman, 2006; Middel et al., 2014). Scholars generally observe stronger UHI effects in compact urban patterns than in dispersed urban patterns where the sources of heat are less concentrated and built areas intermeshed much more with vegetation (Brazel et al., 2007, Ewing and Rong, 2008; Kikegawa et al., 2003; De Munck et al., 2013). For instance, Aguejdad et al. (2012) found that disconnected built patterns reduce the impact area of the UHI by a factor of five to six compared to interconnected built patterns. Yet Lemonsu et al. (2015) found few differences between the UHI of a compact Paris city and a sprawling Paris city by 2100 (difference less than $0.2^{\circ} \mathrm{C}$ ): city fractions affected by different UHI thresholds are more numerous in the dense compact city than the greener sprawling city at night (built density enhances the UHI at night by reducing the amount of radiant energy lost by the surface). Conversely the UHI effect is lower in the compact Paris city during daylight (built density reduces the daytime UHI through shadow). Finally, Masson et al. (2013) reported a slight increase in summertime UHI and a $0.5-1{ }^{\circ} \mathrm{C}$ decline in winter UHI for moderate compact and green urban growth scenarios for the urban area of Toulouse (south-west France) in 2100 as compared to present-day conditions. These scenarios include the protection of existing green and agricultural areas, urban containment strategies such as green belt strategies, construction of moderately dense neighborhoods composed of strips of detached and semi-detached houses, or apartment buildings, and for some scenarios increased vegetation cover in open spaces, on sidewalks, and in parking lots. However, the highest increase in the summer UHI intensity $\left(+1^{\circ} \mathrm{C}\right)$ in the Toulouse suburbs and greatest decrease in its inner core $\left(-2{ }^{\circ} \mathrm{C}\right)$ are reported for a scenario that combines a locally very dense urban development (construction of high-rise multifamily housing) and the absence of urban development in a large and unbroken ecological conservation area.

Changes in the urban built pattern also result in modified patterns of building energy demand (Santamouris 2001). It seems that compact cities increase cooling energy requirements by increasing the number of cooling degree-days more than they reduce the number of heating 
degree-days (Ewing and Rong, 2008; Kolotroni et al. 2011). Yet, this rule depends on the study cases. For instance, UHIs were shown to contribute more to the annual energy savings by reducing the heating energy demands (-20\%) instead of increasing the cooling energy demands (+8\%) in Magli et al. (2015) for Modena (Italy). Masson et al. (2013), also, found a reduction in the space heating energy demands by a factor of three for their green and moderate compact city scenarios for Toulouse by 2100 . However, alongside spatial planning options, these scenarios integrate virtuous individual energy consumption behaviors, suggesting that the behavior of individuals and the thermal properties of buildings drive the heating or cooling energy demands much more than UHI intensities. This is in agreement with the research results of Ewing and Rong (2008), who found that the housing effect (i.e. preferential construction of tall multi-storey and multifamily attached housing on smaller plots in compact cities as compared to sprawling residential developments) influences building energy consumption much more than UHI effects for several US cities.

Urban growth scenarios proposed by Masson et al. (2014) for Toulouse by 2100 that exhibit the lowest UHI effects and the highest heating energy savings contradict some of the recommendations made for limiting the negative effects of urban sprawl, especially the fragmentation of natural and agricultural lands. On the one hand, green belt planning strategies create leapfrog urban developments (Vyn, 2012; Peeters et al., 2015). On the other hand, patterns of small but connected patches of wildlife habitats seems to be a good way to preserve ecological biodiversity (Forman, 1995; Kindelmann et al., 2005).

Considering this, in this paper, we study how different spatial planning policies designed to limit the negative effects of urban sprawl, especially the fragmentation of natural and agricultural lands, impact the UHI intensities and energy demands in buildings. We focus on the Strasbourg-Kehl cross-border urban region (France-Germany) for which we were able to collect accurate high-resolution data in order to conduct our study properly. In addition to that, we do not consider cooling energy demand because the predominant building energy demand is for space heating,

Studies addressing the influence of urban form on the UHI and energy demands in buildings rarely take into account urban change dynamics (Masson et al. 2014). More often than not, a comparison is made between the meteorological simulations of a control run, featuring the impervious built areas of an urban region at a given point in time, with a sensitivity run in which all built areas of the region under study are replaced by vegetation or past urban patterns (Koopmans et al., 2014, Feng et al. 2012, Shem and Shepherd 2009, Zhang et al. 2010, Tokairin et al. 2010, Wang et al. 2012). Nonetheless, some numerical experiments have simultaneously addressed the influence of urban change dynamics on the urban heat island and/or energy demands in buildings (Masson et al. 2014; Lemonsu et al. 2015; Alexander et al. 2016). These studies associate advanced cellular automata-based urban growth models with sophisticated urban canopy models, which account for the three-dimensional outdoor and indoor energetics and dynamics of the buildings. Similarly, in this paper, we adopt a three-step method based on the use of the SLEUTH* cellular automata urban growth model (Houet et al., 2016) and the WRF/urban climate modeling system (Skamarock et al., 2008; Martilli et al., 2002; Salamaca et al. 2010). The first model simulates patterns of residential 
development scenarios. The second assesses the impacts of urban development scenarios on the UHI and building energy demand. Two additional software applications are used to generate urban development scenarios in accordance with realistic spatial planning policies: MorphoLim (Tannier et al. 2011) and Graphab (Foltête et al. 2012). As in Tannier et al. (2016), MorphoLim is used to delineate built clusters and spatially distribute new urban developments whereas Graphab is used for identifying woodland habitats that should be protected with regard to their contribution to the connectivity of the whole regional ecological network.

Previous studies (Masson et al., 2014; Lemonsu et al., 2015) handle several parameters of the urban change dynamics, simultaneously (e.g. building renovation, alternative building geometries, socio-economic scenarios) whereas we target only the impact of the macro-scale urban forms on the space heating energy demands in buildings. Thus, no changes in the building geometry, insulating properties, and household behavior are represented.

Three types of built developments have been simulated and compared: compact, moderately compact, and spontaneous developments. The compact and moderately compact scenarios represent a tight control over urban development and result in infilling and edge growth urban developments, respectively. The spontaneous scenario is a kind of neutral landscape scenario (Gardner et al., 1987; Hagen-Zanker and Lajoie, 2008), for which a randomized situation is created starting from the 2010 initial built pattern. The only planning constraint taken into account is the delineation of non-developable zones set in the urban development plan of the region under study.

\section{Data and study area}

The study was conducted over Strasbourg-Kehl urban region (Fig. 1, France-Germany) and its main urban center, Strasbourg (48 $35^{\prime} 05^{\prime \prime N}$ and $7^{\circ} 45^{\prime} 02^{\prime \prime E}$, elevation: ca. $\left.132 \mathrm{~m}\right)$. With 768,868 individuals (INSEE 2012), the Strasbourg metropolitan area is one of about twenty medium-sized cities of France. This study area is characterized by a high population density and the concentration of skilled tertiary and industrial jobs. Unlike Toulouse agglomeration (43 36' 16" North, 1²6' 38" East; 920, 402 inhab.), studied by Masson et al. (2014), Strasbourg-Kehl urban region is characterized by a loss of attractiveness. Actually, a small positive population growth is currently reported in the urban agglomeration of Strasbourg (+0.4\% between 2007 and 2012; INSEE 2012). Still, an increasing demand for housing and floor space per capita in housings are observed in the meantime.

As shown in Figure 1, residential property, transportation infrastructure, retail services, and production units make up one-third of the land uses in the study area. The remaining land is fertile loess agricultural soils (47\% of the total area) and natural land 0 (16\% of the study area), currently protected by European environmental directives (79/409/EEC, 92/43/EEC, and 2000/60/EEC). With an oceanic climate characterized by well-defined seasons (Köppen type Cfb, cold and foggy winters and continental climatic influences in summer) the study area is characterized by a predominant space heating energy demand (ASPA 2012). Currently, 
only 3.6\% of the French dwellings are equipped with an air conditioning according to the French ministry for Ecology and Sustainable Development (www.developpementdurable.gouv.fr/IMG/pdf/Rapport clim Art5 LG1 280811.pdf). The equipped dwellings are, mainly, located in the South of France. With the global warming trend, the climate of Strasbourg is expected to be similar to the climate of the South of France by 2100. According to the regional direction of industry, research and environment (DRIRE 2000), the air conditioning is not expected to increase significantly in the North of France. Moreover, the penetration of the air conditioning units in the residential dwellings is very difficult to predict. Thus, we focus only on the space heating energy demand in buildings, and exclude the cooling energy demand.

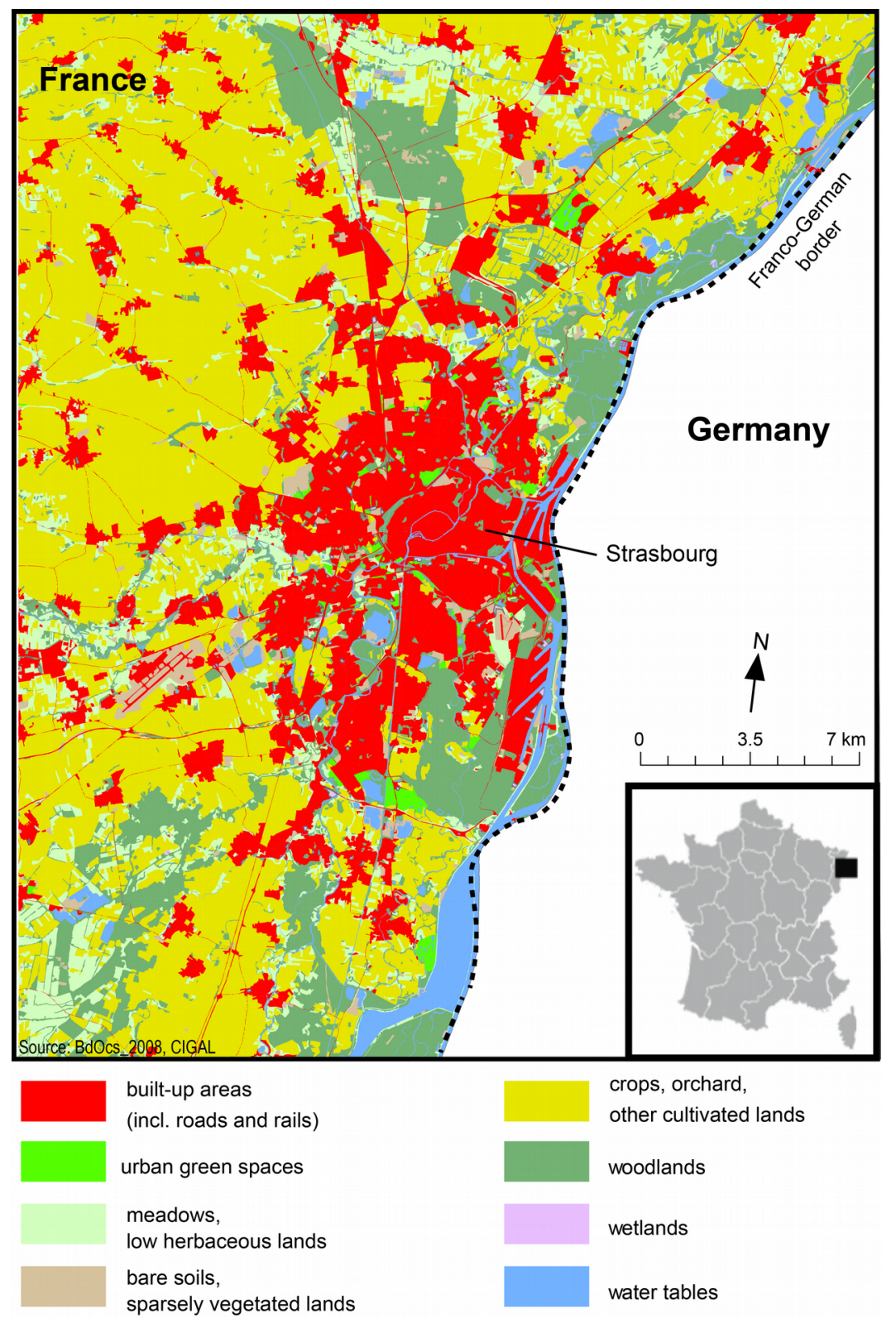

Fig. 1. Land use land cover in the Strasbourg-Kehl urban region

The availability of a high-resolution housing, population, and land use land cover data were, also, considered in choosing the Strasbourg-Kehl urban region. The 2D vector 2012 IGN 
BdTOPO ${ }^{\circledR}$ building database of the National Geographic Institute (IGN, http://professionnels.ign.fr/bdtopo), which maps in 2D all built elements larger than $1 \mathrm{~m}^{2}$ throughout the metropolitan area of Strasbourg, was used to describe the building geometry of the housing stock. The 1999 updated population census of the National Statistics Institute (INSEE) was used to quantify the dwelling floor density of the three urban types taken into consideration in the climate modeling: the high intense residential urban type, the low intense residential urban type, and the commercial and industrial urban type. The urban and regional plans (e.g. the local development plan) from the local urban stakeholders and planning agencies allowed us to design realistic urban development scenarios. Finally, a detailed 2000 and 2008 regional land use databases provided by the regional cooperation for geospatial information CIGAL ${ }^{\circledR}$, respectively BdOcs_2000 and BdOcs_2008, were used to quantify the intensity of urbanization from 2000 to 2008 for the urban area of Strasbourg. The BdOcs_2000 is compiled from interpretations of 23 m-resolution multispectral IRSS Indian satellite images and 15 m-resolution 1997 orthophotographs of the French National Geographical Institute (IGN). The BdOcs_2008 combines the 2.5 m-resolution SPOT 5 satellite images, the $50 \mathrm{~cm}$-resolution 2007 IGN orthophotographs, and local land registries. Since the BdOcs_2008 is more precise, it has been made consistent with the BdOcs_2000 (clustering of the 2008 land use categories; inventory of built land changes of more than 2500 $\mathrm{m}^{2}$ ). In total 745.75 ha were converted into built areas in eight years in the study area, which corresponds to an urbanization intensity of 93.22 ha per year. Assuming that the urbanization rate remains uniform over the simulation period, we calculate that 1864 ha of land will be built by 2030 .

\section{Urban development scenarios}

\subsection{Description of the scenarios}

Six archetypal urban development scenarios at the 2030 time horizon have been devised (Table 1). In the spontaneous development scenarios, the locations of new urban expansions are almost uncontrolled resulting in a scattered pattern of newly built cells. In the compact development scenarios, urban expansions correspond to an infilling growth close to the roads located within built clusters. In the moderately compact development scenarios, urban expansions are located on the fringes of existing urban clusters (i.e. edge growth).

For each of these types of urban development, we have defined an alternative scenario, for which the built expansions are constrained by the protection of woodland ecological habitats conducive to the flow of mammal species across the regional ecological network. To identify those crucial woodland habitats, we chose to focus on the habitat of the red squirrel (Sciurus vulgaris), a common and abundant rodent species shortlisted on the IUCN Red List (IUCN 2013), which has been found to be extremely sensitive to the fragmentation of its home habitats. The disappearance of this species, due to its commonness and abundance, would reflect substantial environmental damage. 
Table 1. Description of the six urban development scenarios

\begin{tabular}{|c|c|}
\hline \multicolumn{2}{|l|}{ Spontaneous development scenarios } \\
\hline No ecological considerations (S1) & Ecological considerations (S2) \\
\hline $\begin{array}{l}\text { Patterns of new urban developments are scattered. } \\
\text { Urban development can occur anywhere in the study } \\
\text { area, except in the non-developable areas of } \\
\text { Strasbourg's local development plan or areas protected } \\
\text { by European conventions. }\end{array}$ & $\begin{array}{l}\text { Same as } \mathbf{S 1}+\text { preservation of the woodlands that } \\
\text { ensure the connectivity of the red squirrel ecological } \\
\text { network. }\end{array}$ \\
\hline \multicolumn{2}{|l|}{ Compact development scenarios } \\
\hline No ecological considerations (S3) & Ecological considerations (S4) \\
\hline $\begin{array}{l}\text { Patterns of new urban developments are concentrated. } \\
\text { Urban development can occur only within the limit of } \\
\text { existing built clusters (in the vacant spaces, brown } \\
\text { fields, and developable zones of Strasbourg's local } \\
\text { development plan). } \\
\text { Locations close to existing roads are favored. }\end{array}$ & $\begin{array}{l}\text { Same as } \mathbf{S 3}+\text { preservation of the woodlands that } \\
\text { ensure the connectivity of the red squirrel ecological } \\
\text { network. }\end{array}$ \\
\hline \multicolumn{2}{|l|}{ Moderately compact development scenarios } \\
\hline No ecological considerations (S5) & Ecological considerations (S6) \\
\hline $\begin{array}{l}\text { Patterns of new urban developments are moderately } \\
\text { concentrated. } \\
\text { Urban development occurs preferentially on the } \\
\text { fringes of existing built clusters in the developable } \\
\text { zones of Strasbourg's local development plan. }\end{array}$ & $\begin{array}{l}\text { Same as } \mathbf{S 5}+\text { preservation of the woodlands that } \\
\text { ensure the connectivity of the red squirrel ecological } \\
\text { network. }\end{array}$ \\
\hline
\end{tabular}

\subsection{Transcription of the spatial planning rules into maps of non-developable areas}

For all scenarios, the existing built pattern, thae hydrological networks, and the transportation infrastructures are non-developable, as well as the German part of the study area that represents almost 27,500 ha (about 30\% of the study area). In addition, urban developments cannot occur in areas where the slope is greater than $90 \%$ or in areas marked as nondevelopable in the 2012 local development plan of the Strasbourg Eurometropolis. Finally, all land listed by European and French directives on biodiversity (RAMSAR, ZNIEFF, Birds Directives, etc.) is precluded from urbanization. The resulting map of non-developable areas is used for scenario $\mathrm{S} 1$, which is the least restrictive one. 
For the compact and moderately compact scenarios, the limits of built clusters existing in 2010 have been taken into account in order to constrain and spatially distribute the simulated urban developments either within the clusters or on their fringes. For this, we have used the MorphoLim software application (Tannier et al. 2011), which delineates morphologically coherent built clusters according to a geometrical fractal logic. The principle is that the regularity found in the spatial distribution of buildings and empty spaces varies regularly across scales, from the neighborhood scale to the regional scale. Any marked disruption of this spatial regularity can be used to identify a crucial distance threshold specific to a given level of aggregation of coherent built clusters.

We have applied MorphoLim on the vector 2012 IGN BdTOPO ${ }^{\circledR}$ database. The distance threshold identified is equal to $133 \mathrm{~m}$, meaning that all buildings separated by a distance of less than or equal to $266 \mathrm{~m}$ belong to the same built cluster. For the compact scenarios, the simulated development takes place within all built clusters whatever their size. For the moderately compact scenarios, the simulated development takes place within a buffer zone around each built cluster. The width of this buffer zone is proportional to the size of the corresponding built cluster.

Finally, for scenarios S2, S4, and S6, we have identified woodland habitat areas of the Red squirrel that should be spared from urbanization with regard to their contribution to the connectivity of the ecological network under consideration. For this, we have used Graphab (version 1.1.), a GIS integrated application for modeling ecological networks of animal species (Foltête et al. 2012). Graphab relies on graph theory. Usually, a graph defines a set of nodes connected by links (or edges) that are characterized by attribute elements. Applied to landscape ecology, nodes are discrete elements of a landscape that are home to a single focal species (habitat patches). Links are functional connections or pathways between two habitat patches that characterize the permeability of the landscape to species movements taking into account human disturbances (Urban et al. 2009). The dispersal probability of individuals from a patch origin $i$ to a patch destination $j$ is inversely proportional to the least-cost distance $\mathrm{d}_{\mathrm{ij}}$ between patches $i$ and $j$ :

$p_{i j} e^{-\alpha d_{i j}}$

with $\alpha$ an extinction coefficient computed by Graphab that expresses the intensity of the decrease in the dispersal probabilities included between 0 and 1 .

Data used as input in Graphab were the BdOcs_2008 land-use map rasterized at $10 \mathrm{~m}$ resolution. We have attributed contrasted costs to each type of land use according to the extent of human perturbations. The value 1 was assigned to woodlands, 10 to other land-use types favorable to red squirrel movements, and 100 for land-use types highly perturbed by human activities. The maximum dispersal distance of the red squirrel was set to $1.5 \mathrm{~km}$, allowing us to truncate the ecological graph and so better represent the red squirrel's capacity for movement. Based on this, we computed two connectivity indexes in order to assess the degree of interconnection between all pairs of nodes: $\mathrm{dPC}_{\text {flux }}$ (larger home patches mean a larger population), and consequently a higher migration rate, and $\mathrm{dPC}_{\text {connector }}$ (intermediate 
patches in the graph favor population flows in unfavorable environments) (Pascual-Hortal and Saura 2007; Saura and Rubio 2010). This latter index allowed us to identify crucial habitat patches that ensure the connectivity of the red squirrel ecological network (Fig. 2). We observe that the ecological graph for the red squirrel exhibits four components: one main graph and three small disconnected components. The connection between the northern and southern structures of the main graph depends mainly on the preservation of small hardwood forests. Woodlands in dark gray are already protected by the local development plan for Strasbourg and European environmental directives.
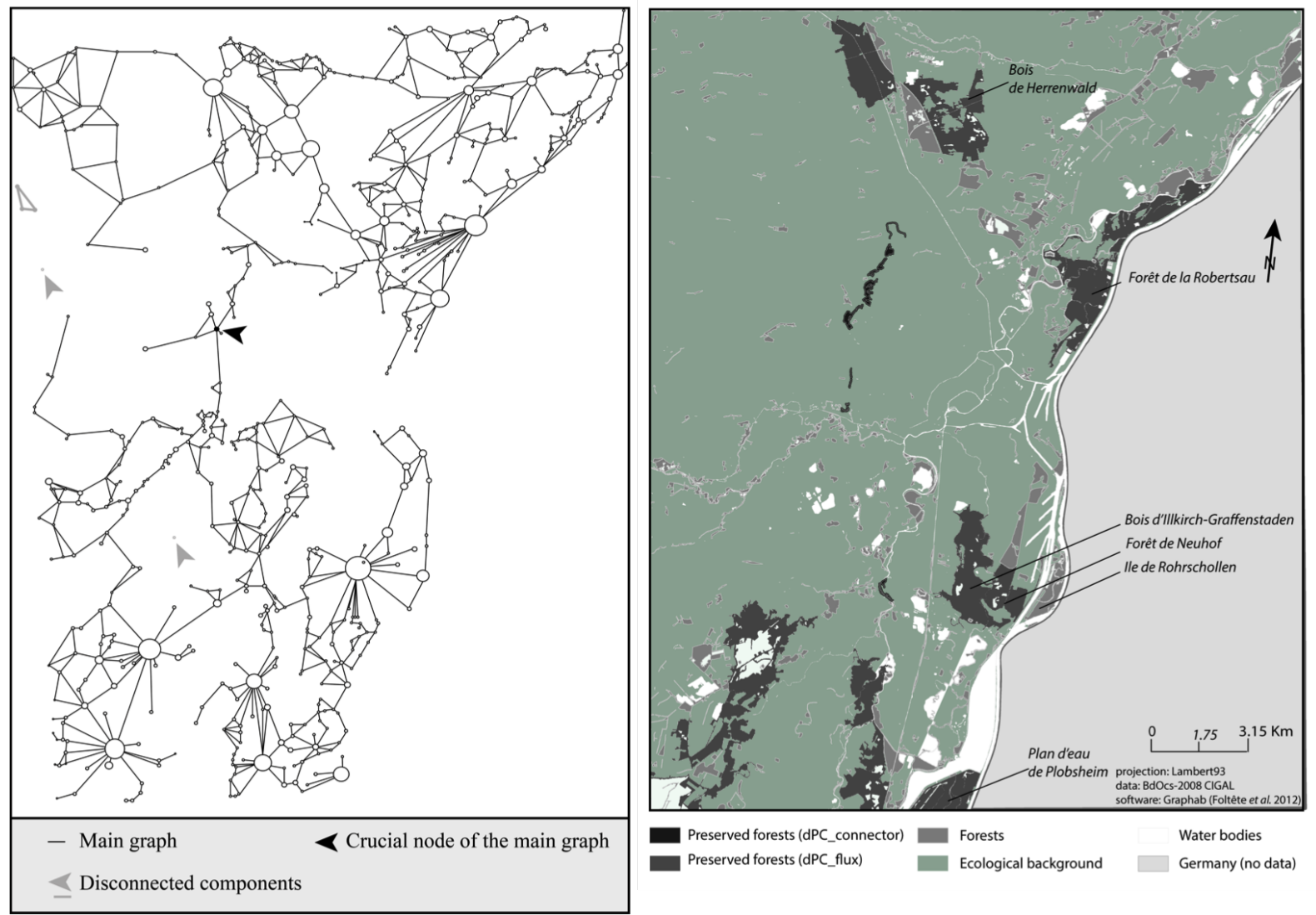

Fig. 2. Forested areas protected against urbanization in order to preserve the red squirrel ecological network. Right: woodland habitats that should be preserved due to their size (dPC_flux) or their relative positions (dPC_connector). Left: graphs of the Red Squirrel habitat for the study area. Circles represent home habitat patches proportional to their area. Lines are the shortest paths between two disjointed home habitats.

Finally, Fig. 3. shows the non-developable maps defined for each residential development scenario. Unsurprisingly, developable areas are much larger for the spontaneous residential development scenarios than for the moderately compact development scenarios and a fortiori the compact development scenarios (Table 2). 

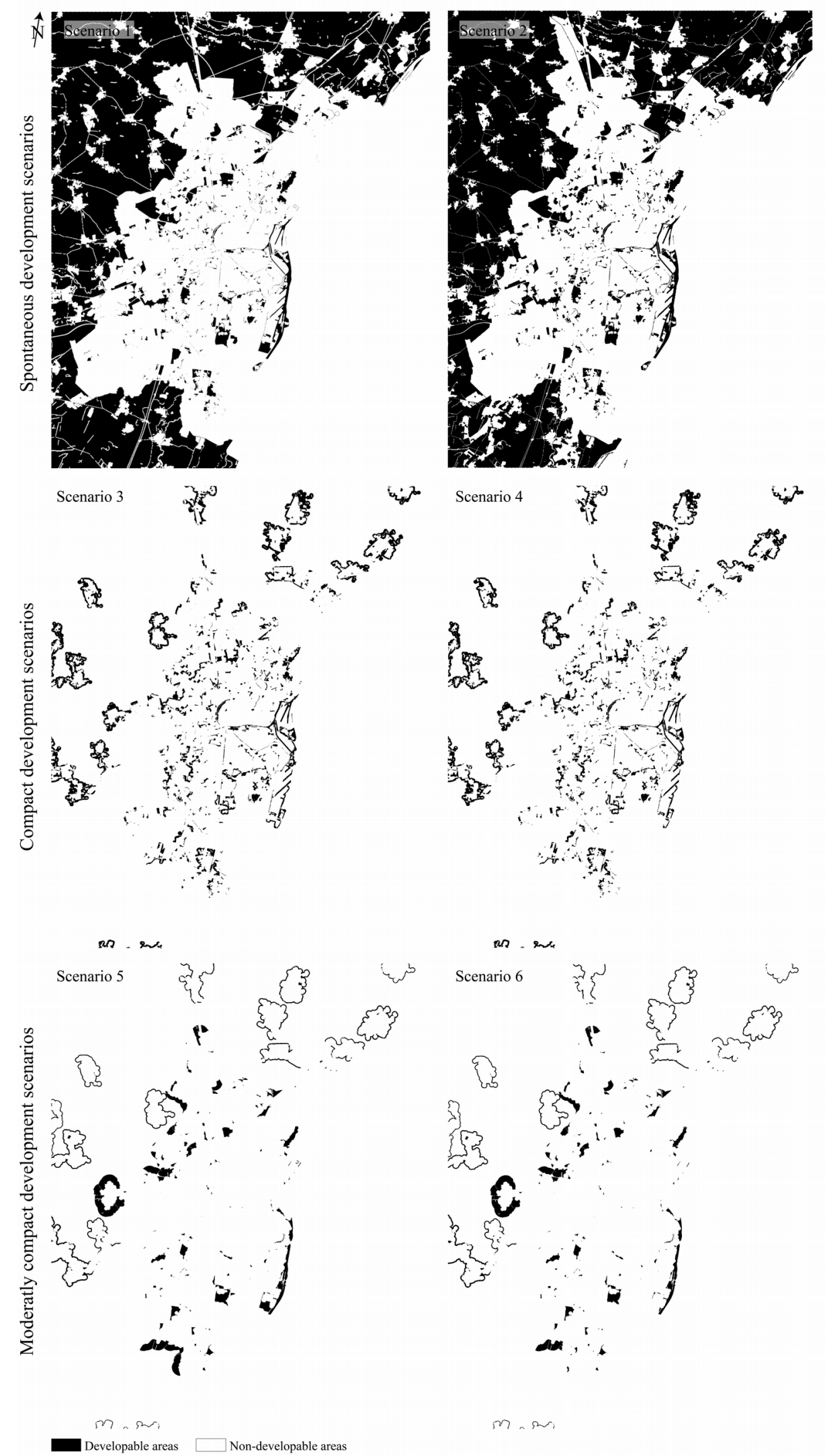

Fig. 3. Non-developable areas for the six simulated scenarios 
Table 2

Spatial extent of developable areas for the six simulated scenarios

\begin{tabular}{|l|l|}
\hline \multicolumn{2}{|l|}{ Spontaneous development scenarios } \\
\hline S1 & S2 \\
\hline $34,126.68$ ha & $27,577.32$ ha \\
\hline Compact development scenarios \\
\hline S3 & S4 \\
\hline 2,407.80 ha & $2,407.32$ ha \\
\hline Moderately compact development scenarios \\
\hline S5 & S6 \\
\hline $2,918.84$ ha & $2,748.00$ ha \\
\hline
\end{tabular}

\subsection{Settings of the SLEUTH* simulation model of urban growth}

The SLEUTH* urban growth model of Houet et al. (2016) was used to simulate the residential development in the study area by 2030. SLEUTH* is a modified version of SLEUTH (Clarke et al. 2008). It has been developed specifically for use in a fully controlled forecasting mode. SLEUTH* requires as input four maps: existing buildings, nondevelopable areas, slopes, and the road network. The input data used in SLEUTH* were the BdOcs_2008 land-use map rasterized at $20 \mathrm{~m}$ resolution. Like any cellular automata model, SLEUTH* is a self-organizing system composed of land use grid cells. Transition rules drive the land use changes of each grid cell according to both the state of the grid cell itself and the state of the neighboring grid cells. Four parameters (each ranging from $0 \%$ to $100 \%$ ) enable users to choose the type of urban development simulated: spontaneous, concentrated in new spreading-center, ribbon or edge growth, close to existing roads, or some combination of each type of development. Transition rules chosen for each type of urban development are given in Table 3. Additionally, for the compact development scenarios, road attractiveness has been set to $100 \mathrm{~m}$ in order to promote development close to existing roads.

\section{Table 3}

SLEUTH* urban growth rules chosen for simulating three types of residential development

\begin{tabular}{|l|l|}
\hline Spontaneous development & $100 \%$ spontaneous growth \\
\hline Compact development & $50 \%$ road-influenced and 50\% edge growth \\
\hline Moderately compact development & $50 \%$ spontaneous and $50 \%$ edge growth \\
\hline
\end{tabular}

\subsection{Morphological analysis of the simulated built patterns}

We obtained two series of three urban development scenarios, whose resulting urbanization patterns are presented in Fig. 4 and Fig. 5. For four scenarios out of six, the targeted urban growth has been achieved (1864 ha). By contrast, the compact scenarios achieve only $63 \%$ of the targeted urban growth. 

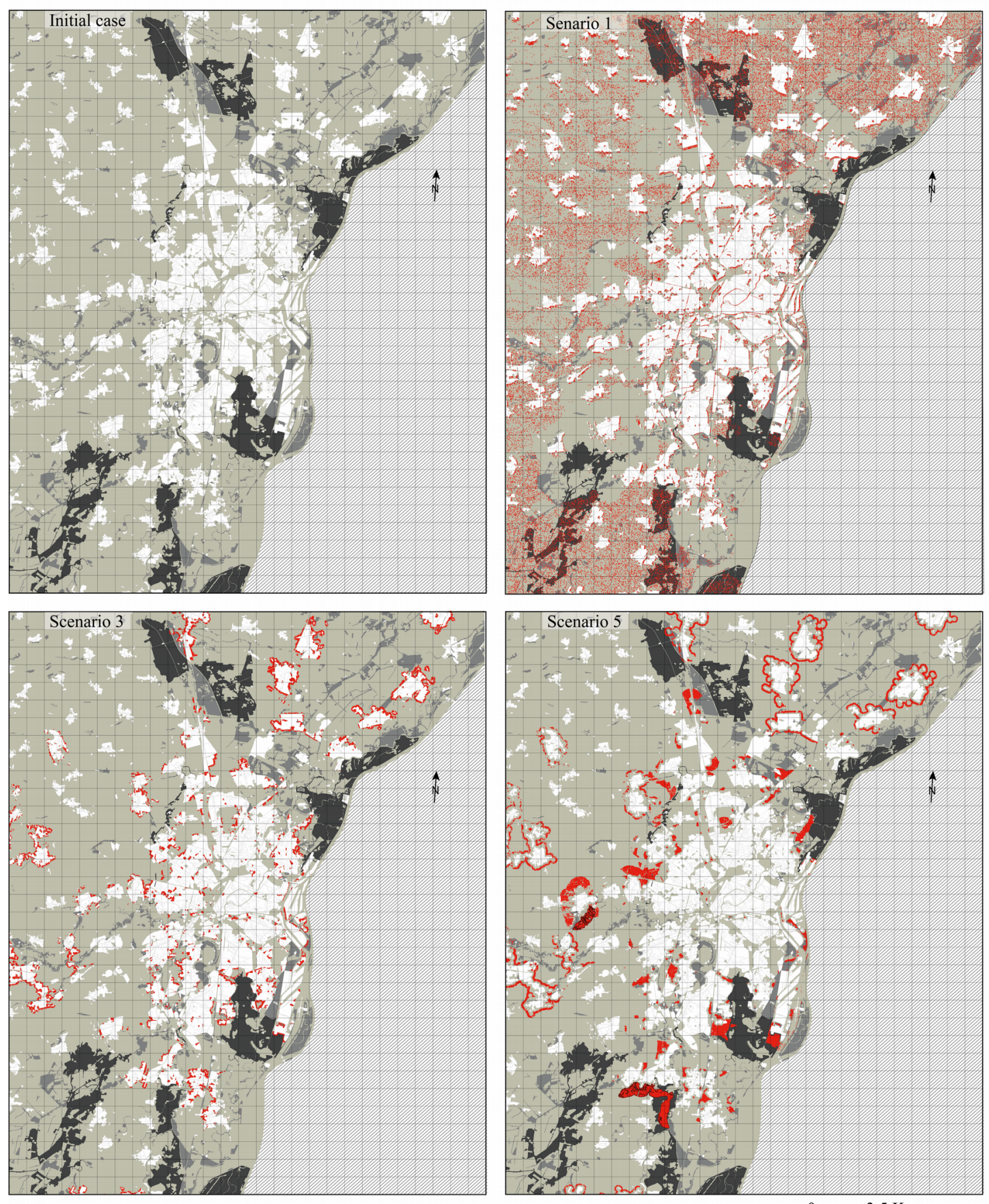

Ecological background

Woodlands

Protected woodlands

/ / Germany

2010-2030 built clusters

Atmospheric grids projection: RGF Lambert93

Fig. 4. Built patterns of the initial case and the three types of urban development 

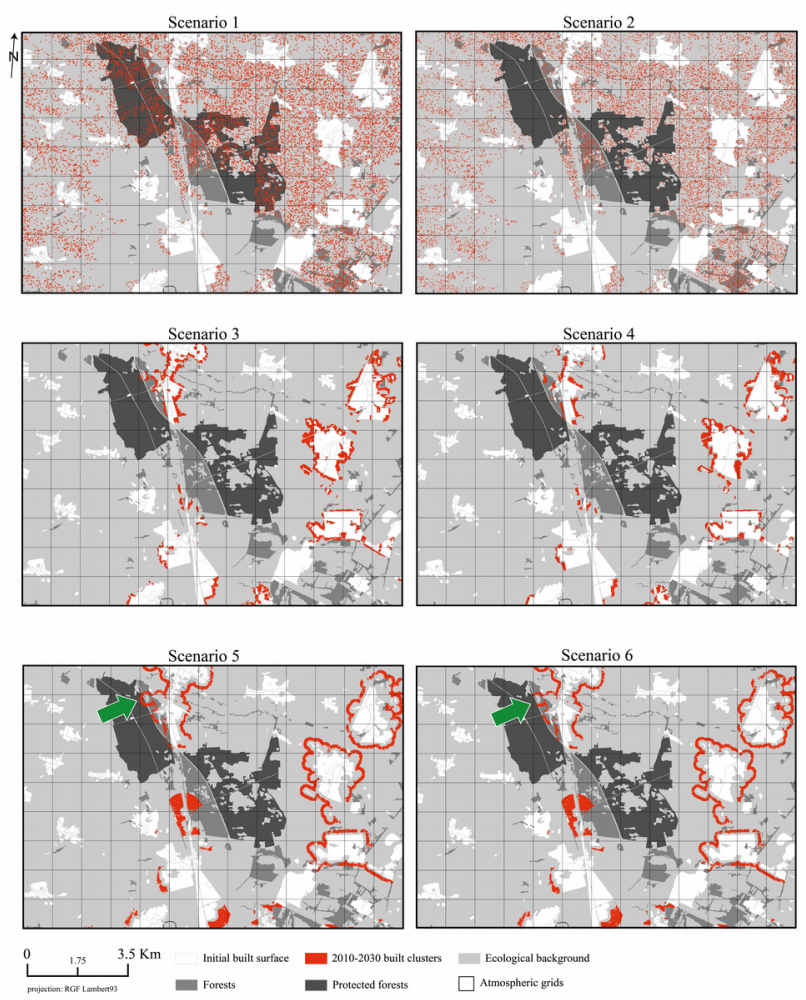

Fig. 5. Local built patterns generated by simulation: focus on 3532.10 ha, north of Strasbourg. The arrows in S5 and S6 highlight the only small difference in the developed areas between the two scenarios. 
Three morphological indexes characterize the simulated built patterns resulting from each scenario: the 2010-2030 urban development area $\left(\mathrm{A}_{\mathrm{b}}\right)$, the number of built clusters $\left(\mathrm{N}_{\mathrm{b}}\right)$, and the area of the biggest cluster (or main urban center) $\left(\mathrm{A}_{\mathrm{MA}}\right)$ identified for an inter-building distance of $266 \mathrm{~m}$ (Table 4).

\section{Table 4}

Morphological characteristics for the six scenarios and initial case.

\begin{tabular}{lrrr} 
& $A_{b}($ in ha $)$ & $N_{b}$ & $A_{M A}\left(\right.$ in $\left.\mathrm{km}^{2}\right)$ \\
\hline Initial case & No & 346 & 140.90 \\
\hline Scenario 1 & 1,864 & 85 & 509.69 \\
\hline Scenario 2 & 1,864 & 104 & 491.69 \\
\hline Scenario 3 & 1,185 & 319 & 151.60 \\
\hline Scenario 4 & 1,182 & 322 & 150.26 \\
\hline Scenario 5 & 1,864 & 256 & 201.29 \\
\hline Scenario 6 & 1,864 & 256 & 199.84 \\
\hline
\end{tabular}

The simulated built patterns are well contrasted. The spontaneous development scenarios (S1 and S2) are characterized by a very large and sprawling main urban center. The number of built clusters is very low, which is explained by the large extent of the main urban center. The compact development scenarios (S3 and S4) exhibit the highest number of built clusters and the smallest main urban center. Finally, the moderately compact development scenarios (S5 and S6) are in-between the compact and spontaneous development scenarios, but closer to the former than the latter.

The introduction of woodland preservation rules barely modifies the simulated built-up patterns. Consequently, the three ecological alternative scenarios S2, S4, and S6 are omitted from further simulations with the WRF/urban climate modeling system.

\section{Coupling the SLEUTH* simulation results with the WRF/urban climate modeling system}

\subsection{The WRF/urban climate modeling system}

The WRF/urban climate modeling system consists in the non-hydrostatic Weather Research and Forecasting (WRF) model of Skamarock et al. (2008) and its BEP+BEM urban canopy parameterization (Martilli et al. 2002; Salamanca et al. 2010). The WRF/urban climate modeling system computes the evolution of the meteorological variables (i.e. the wind speeds, the potential air temperatures, and the specific humidity) on the atmospheric grid cells. For this purpose, the WRF/urban climate modeling system needs information on the surface, the nature of the land cover and its associated physical static properties (i.e. albedo, 
soil water content, and the like). The Noah LSM land surface model (Chen 2007) and the BEP+BEM urban canopy model (Martilli et al. 2002; Salamanca et al. 2010) compute the effects of the surfaces on the energetics and dynamics of the atmosphere for non-urban and urban cells, respectively. Then, in each urban grid cell, these effects are averaged according to the share of non-urban and urban surface in the cell.

The BEP module computes the bulk momentum, kinetic energy, heat and humidity turbulent fluxes induced by a set of three-dimensional built elements (buildings and streets) that are immersed in a urban atmospheric grid cell for a high-resolution multilayer and vertical canopy grid. It considers (i) the reduced turbulent exchanges in the streets through a walldistributed drag force approach and a modified Bougeault and Lacarrère (1989) scheme; (ii) the shades of the shade surfaces and the reduction of the surface thermal radiation losses taking into account the street orientations and the variations of the building height; and (iii) the different thermal responses of the street-canyon facets with regards to their construction materials and energy storage capacities. Three urban types can be defined in BEP: the high intense residential (HIR) that characterizes very dense city districts with few vegetation, the low intense residential (LIR) that characterizes moderate to low dense city district with much more intermeshed vegetation, and the commercial and industrial estates (COI). The building and street geometries of each of these urban types are described with respect to the arrays of volume-equivalent cubes that are oriented and uniformly distributed in a urban grid cell. In addition to that, a distribution probability function of the building height determines for each urban sample a specific building type composition.

Besides, the Building Energy Model (BEM) computes for each floor of a given building type the indoor energy budget and its energy demand intensity for space heating $\left(\mathrm{ec}_{\mathrm{b}}(\mathrm{t}, \mathrm{i})\right.$ in $\mathrm{Wh} /$ floor $\mathrm{m}^{2}$ ). BEM takes into account the modification of the outdoor temperatures induced by the urban environment (and calculated by BEP), the passive energy gains induced by solar heating through windows, and the wasted heat from building occupants and equipment. In parallel, it considers the energy losses through the building envelop by heat conduction through layered wall systems characterized by different thermal masses, longwave thermal radiations, and unintentional natural ventilation. Compared to a user-defined thermostat setting, the result of this indoor energy budget helps determining the amount of space heating energy that should be supplied in buildings to comply with the indoor thermal comfort expectation. Thereby, the total energy demands in buildings for space heating at a time $t$ in a given urban grid cell $i, e c(t, i)$ is computed by weighting the sum of the space heating energy demands' intensities of each building type $b$ by their respective coverage area $A_{b}(i)$ in the urban grid cell.

$$
e c(t, i)=\sum_{b=1}^{b=n b} A_{b}(i) * e c_{b}(t, i)
$$

For further information on the BEM module, please see Salamanca et al. (2010). 


\subsection{Preparation of the land-use data for the WRF/urban climate modeling system}

Several studies have already stressed that an accurate representation of the surface properties are "critically important" in the urban climate modeling as the surface, by exchanging the momentum, heat, moisture, and mass with the atmosphere condition, the atmospheric turbulent structure (Vogt and Oke, 1998; Pielke and Niyogi 2011), as well as the accuracy of the simulated meteorological fields (Brousse et al., 2016).

The aspects of the surface properties that may be more crucial than the others in the WRF/urban climate modeling system are the total amount of built surfaces immersed in each atmospheric grid cell and the urban fraction threshold. Based on these two variables, the model determines 1) whether an atmospheric grid cell is classified as "urban" or "non-urban" in the computational domain and, then, the activation or not of the BEP+BEM module, and 2) the dominant land cover type of the atmospheric grid cells, which is assumed to be representative of the land cover of the entire grid cell (dominant land cover method).

To prepare the 2030 land cover maps of each scenario, we first attributed to each newly $20 \mathrm{~m}$ urbanized grid cell of the SLEUTH* simulations a urban type that corresponds to one of the three urban types considered in BEP. Therefore, three rules have been set. First, new urban development cannot produce urban densities comparable to the very dense historical center (classified as HIR). Second, the proportion of the non-residential areas compared to the residential areas in 2030 is kept identical with regard to the BdOcs_2008 land cover. Finally, the industrial and commercial estates are randomly spatially distributed among the new urban developments simulated by SLEUTH*. Hereafter, the newly developed $20 \mathrm{~m}$ urban grid cells and the BdOcs_2008 land cover are combined in order to prepare the 2030 land cover map used as input in the WRF/urban climate modeling system.

In the WRF/urban climate modeling system, a dominant land-cover type is attributed to each $1 \mathrm{~km}^{2}$ atmospheric grid cell and is assumed to be representative of the land cover of the entire grid cell. Atmospheric grid cells are classified into "urban" or "non-urban" based on an urban fraction threshold, i.e. the fraction of built surface included in each atmospheric grid cell, and determine whether or not the BEP+BEM module is activated. We opted to reduce the urban fraction threshold from its default setting of $50 \%$ down to $20 \%$, meaning that if more than $20 \%$ of the surface of the atmospheric grid is built, the atmospheric grid cell is classified as "urban". This 20\% threshold value allows us to make a trade-off between an accurate representation of small-scale surface changes and an accurate representation of the vegetation types in each urban grid cell. Indeed, when a grid cell is considered as "urban", the remaining non-built surfaces included in the grid cell are automatically converted by the WRF/urban climate modeling system into a mosaic vegetation type, i.e. a mosaic of croplands, forests, shrub lands and grasslands with none of these vegetation types representing more than $60 \%$ of the total non-built area. This rule is appropriate in representing green surfaces located within the urban area but not for green surfaces located at the periphery of the urban area where vast monoculture and forest areas exist. Table $\mathbf{5}$ shows the errors that result from the conversion of the BdOcs_2008 land cover map into the land use map, which are taken into account by the WRF/urban climate system in increasing the urban fraction thresholds. The 
results indicate that if all the land cover types (see Fig. 6) are considered, a threshold value equal to $30 \%$ or $20 \%$ allows a more accurate representation of the BdOcs_2008 land cover map in the WRF/urban climate modeling system. Whereas, if only the urban built surfaces are considered, the best representation is obtained when a threshold value is equal to $20 \%$.

\section{Table 5}

Error resulting from the conversion of the BdOcs_2008 land cover map into a land use map, and taken into account by the WRF/urban climate system. The area of each land cover class in the BdOcs_2008 map, that is attributed to a wrong class in the land use map taken into account by the WRF/urban climate system, is weighted by the relative share of this land cover in the BdOcs_2008 map.

\begin{tabular}{|l|l|l|}
\hline & \multicolumn{2}{|c|}{ Mean absolute error (in \%) } \\
\hline Urban fraction threshold & All land cover types & Only urban land cover types \\
\hline $0 \%$ & 94.1 & 23.0 \\
\hline $10 \%$ & 38.4 & 24.2 \\
\hline $20 \%$ & 22.6 & 20.6 \\
\hline $30 \%$ & 22.1 & 25.6 \\
\hline $40 \%$ & 23.7 & 34.3 \\
\hline $50 \%$ & 24.9 & 41.7 \\
\hline
\end{tabular}

Table 6 compares the statistical distribution of urban fractions in each atmospheric grid cell before and after the classification according to this 20\% threshold for the three urban development scenarios. We observe that a high proportion of the atmospheric grid cells characterized by the low urban fractions are not considered as urban after the classification. The largest modifications of the statistical distribution of the urban fractions are reported for the spontaneous development scenario.

\section{Table 6}

Statistical distributions of the urban fraction in each atmospheric grid cell.

\begin{tabular}{|l|l|l|l|l|l|l|}
\hline $\begin{array}{c}\text { Statistical } \\
\text { parameters }\end{array}$ & \multicolumn{2}{|c|}{ Spontaneous development } & \multicolumn{2}{|c|}{$\begin{array}{c}\text { Compact } \\
\text { development }\end{array}$} & \multicolumn{2}{|c|}{$\begin{array}{c}\text { Moderately compact } \\
\text { development }\end{array}$} \\
\hline & $\begin{array}{l}\text { After } \\
\text { classification }\end{array}$ & $\begin{array}{l}\text { Before } \\
\text { classification }\end{array}$ & $\begin{array}{l}\text { After } \\
\text { classification }\end{array}$ & $\begin{array}{l}\text { Before } \\
\text { classification }\end{array}$ & $\begin{array}{l}\text { After } \\
\text { classification }\end{array}$ & $\begin{array}{l}\text { Before } \\
\text { classification }\end{array}$ \\
\hline Median & 44.91 & 12.68 & 48.22 & 14.60 & 43.77 & 18.10 \\
\hline $\begin{array}{l}\text { Interquartil } \\
\text { e }\end{array}$ & 30.36 & 27.97 & 34.23 & 39.51 & 32.51 & 38.12 \\
\hline Kurtosis & -0.73 & 0.77 & -0.92 & -0.74 & -0.74 & -0.23 \\
\hline Skewness & 0.54 & 1.31 & 0.40 & 0.51 & 0.51 & 0.89 \\
\hline
\end{tabular}

Table 7 shows the total built area and the corresponding number of urban grid cells considered in the urban climate modeling system using the $20 \%$ rule. The urban climate modeling system considers a larger total built area in compact and moderately compact scenarios than in the spontaneous urban development scenarios although SLEUTH* 
urbanized only 63\% of the 2010-2030 expected urban development areas in the compact development scenarios. Consequently, the dominant land-cover method appears to be inappropriate for studying scattered built patterns, and scenario 1 has not been retained for the further climate simulations. Fig. 6 displays the land-use maps taken into account by the WRF/urban climate modeling system, while Fig. 7 shows the corresponding urban fractions and grid cells where the amount of built up areas has increased.

\section{Table 7}

Urban grid counts $(\mathrm{Nb})$ and corresponding urban grids' built-up areas $A_{b}$ taken into account in the WRF/urban climate modeling system.

\begin{tabular}{llc} 
& $\mathrm{Nb}$ & $A_{b}\left(\mathrm{in} \mathrm{km}^{2}\right)$ \\
\hline Scenario 1 & 188 & 87.24 \\
\hline Scenario 3 & 184 & 89.83 \\
\hline Scenario 5 & 210 & 98.00 \\
\hline
\end{tabular}

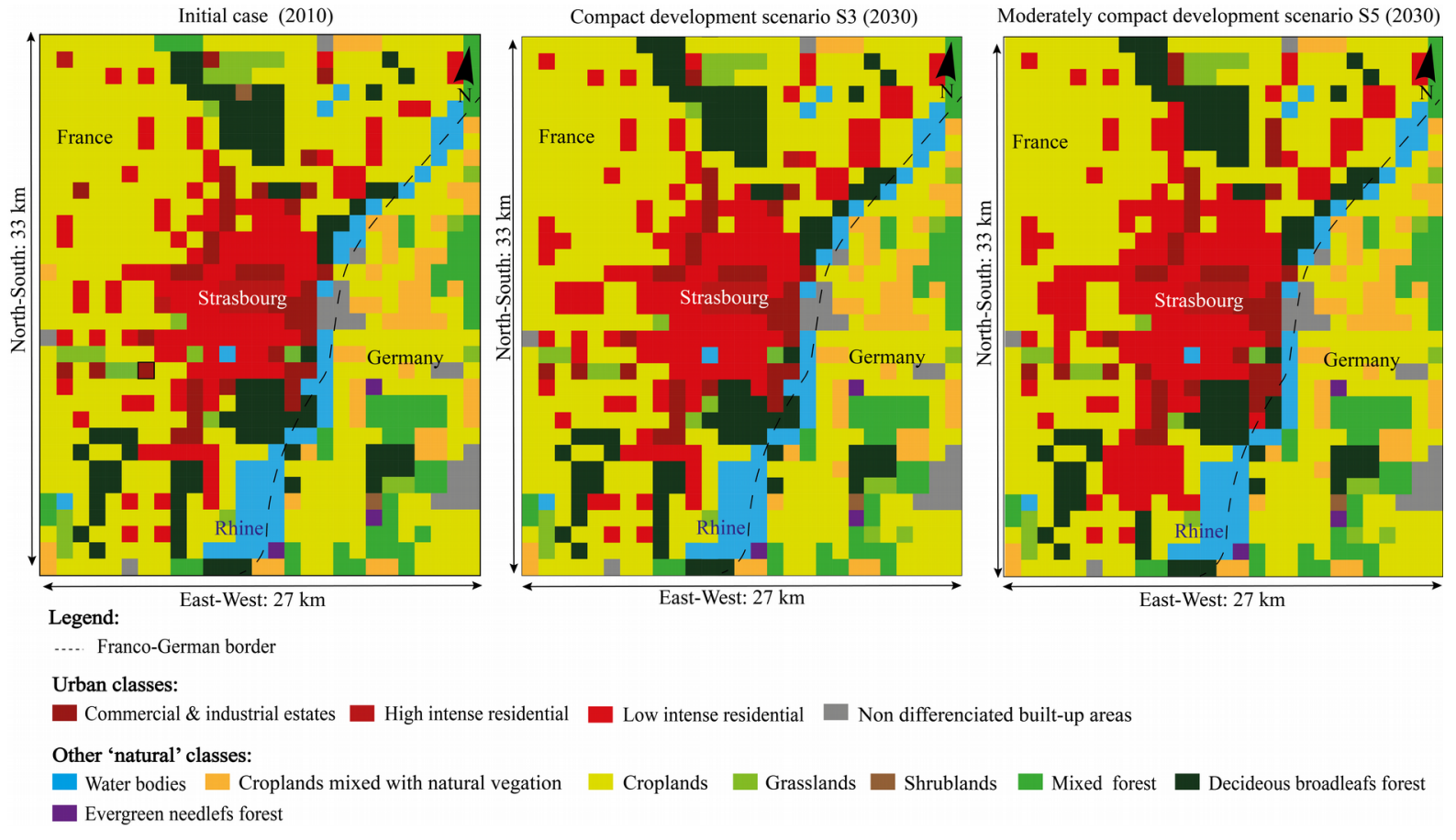

Fig. 6. Land-use maps taken into account by the WRF/urban climate modeling system 

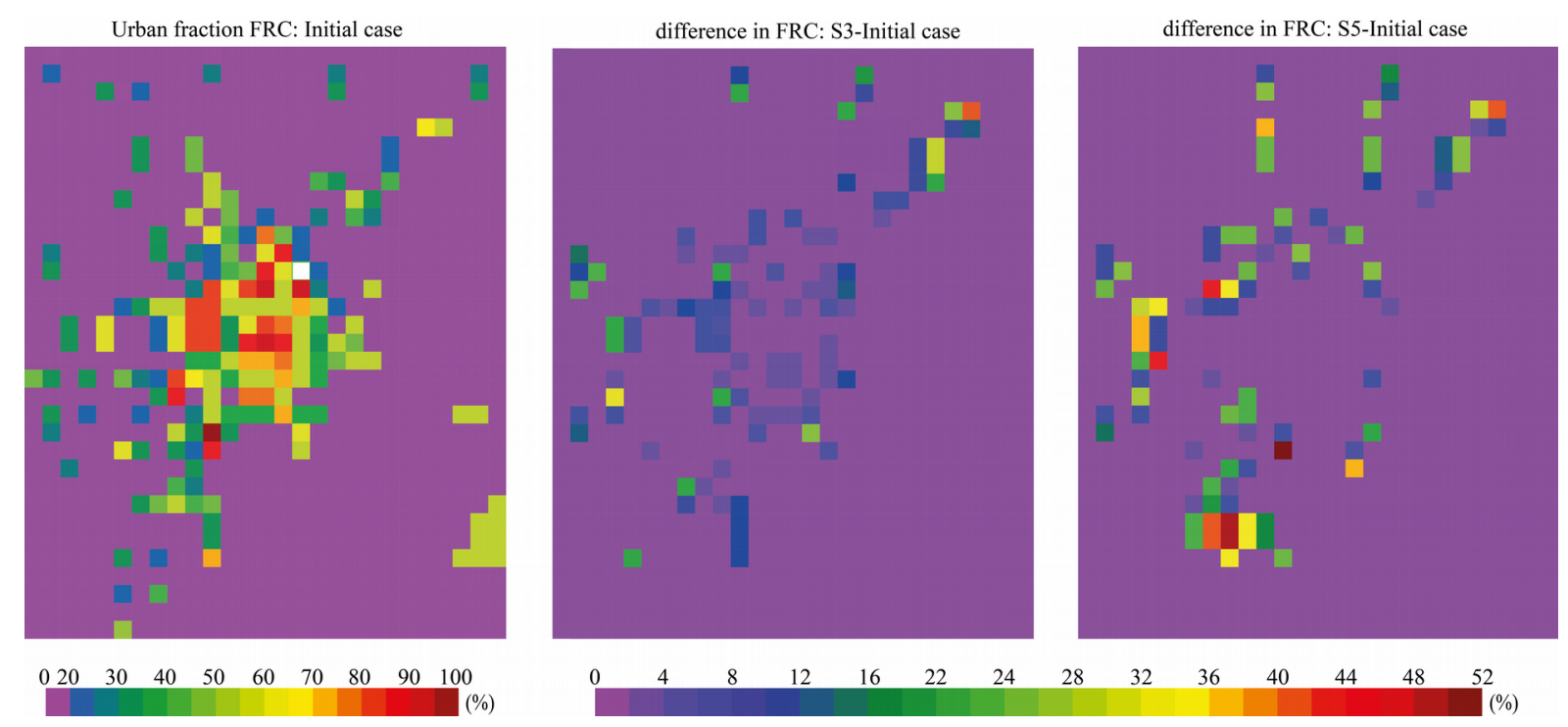

Fig. 7. Urban fraction maps and differences in (\%) between the compact and moderately compact scenarios and the initial case.

\subsection{Other settings of the WRF/urban climate modeling system}

Simulations are performed for February, March, and September 2010, which was one of the warmest years in the last 130 years worldwide. At a local scale, the winter of 2010 was particularly cold. Therefore, this year represents not only the global warming trend that European cities have to adapt to, but also the extreme of the regional climate variability. The horizontal domain is composed of four two-way nested and embedded domains with horizontal atmospheric grid resolutions of $45 \mathrm{~km}, 9 \mathrm{~km}, 3 \mathrm{~km}$, and $1 \mathrm{~km}$ (Fig. 8). Each simulation lasts 5 days with a spin-up time of 5 days for the initialization. The meteorological initial and boundary conditions are from the NCEP Global Final Analysis (FNL) meteorological global data (Research Data Archive at the National Center for Atmospheric Research, http://rda.ucar.edu/datasets/ds083.2). They are provided to the coarsest domain grid every 6 hours with a grid resolution of 30 arc seconds. For the vertical grid, 27 eta-levels with a pressure fixed at the top at 5000 Pascal have been defined. Thereby, 10 eta-levels are included in the first 1.5 kilometers, and can be used to describe the urban canopy layer with accuracy. For the physics, the Dudhia (1989) shortwave radiation scheme and the Rapid Radiative Transfer model longwave parameterization, coupled with the Thompson et al. (2004) microphysics schemes have been selected. The Bougeault and Lacarrère (1989) Planetary Boundary Layer scheme has also been selected as well as the NOAH land surface model (Chen and Dudhia 2001) and a four-layer soil model to take soil moisture into account. The high-resolution BdOcs_2008 land-use database informs the surface coverage for the finest domain of the initial case, in particular the area occupied by impervious surfaces (urban fraction). For the four 2030 scenarios, we used the maps obtained as a result of section 4.2. 


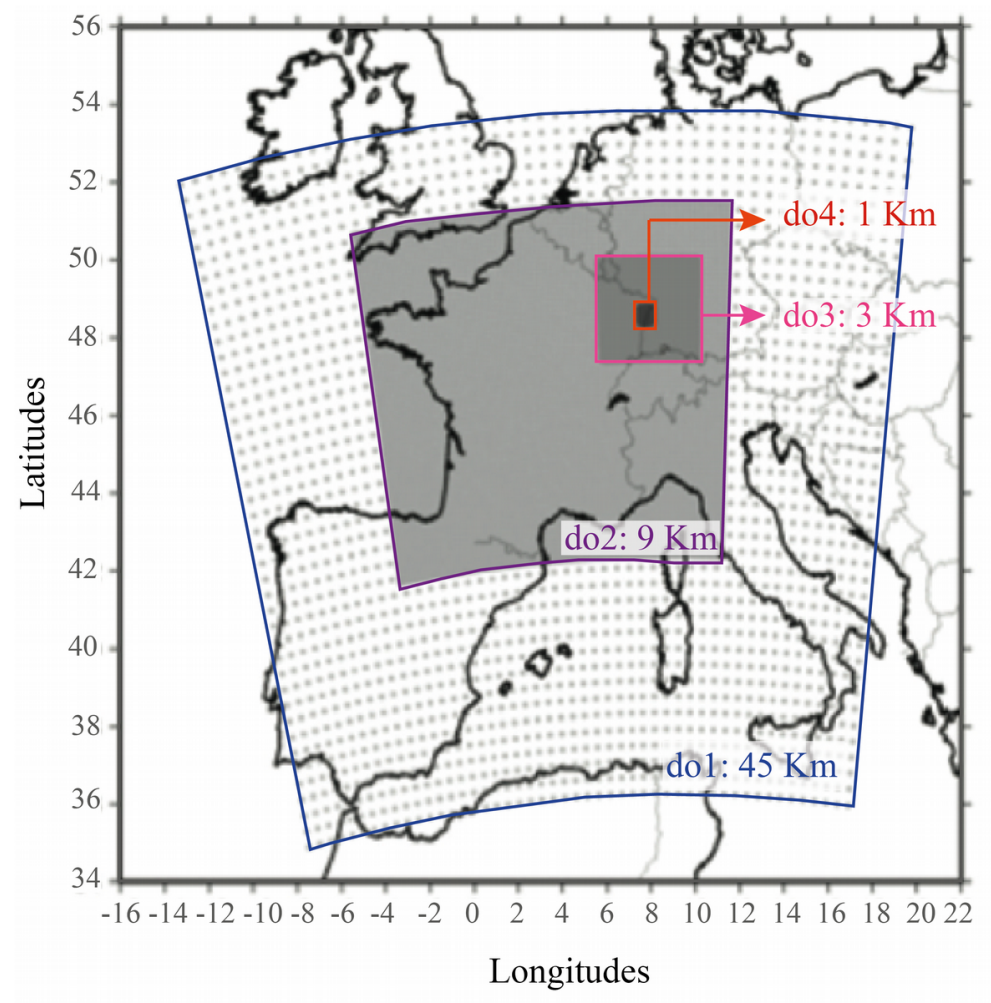

Fig. 8. The four embedded atmospheric horizontal domains

\section{Table 8}

Urban morphological parameters for every urban type. HIR refers to high intensity residential, LIR to low intensity residential, and COI to commercial and industrial properties.

\begin{tabular}{llll}
\hline Parameters & HIR & LIR & COI \\
\hline Floor height (m) & 3 & 3 & 3 \\
\hline Building 5m tall (\%) & 25.0 & 42.0 & 30.0 \\
\hline Building 10m tall (\%) & 54.0 & 51.1 & 49.0 \\
\hline Building 15m tall (\%) & 11.0 & 5.0 & 13.0 \\
\hline Building 20m tall (\%) & 5.0 & 1.3 & 4.0 \\
\hline Building 25m tall (\%) & 4.0 & 0.4 & 2.0 \\
\hline Building 30m tall (\%) & 1.0 & 0.1 & 1.0 \\
\hline Building 40m tall (\%) & 0.0 & 0.1 & 1.0 \\
\hline North/South street-canyon direction ( $\left.{ }^{\circ}\right)$ & 315 & 45 & 0 \\
\hline West/East street-canyon direction ( $\left.{ }^{\circ}\right)$ & 45 & 315 & 90 \\
\hline Street width North/South direction (m) & 5 & 20 & 25 \\
\hline Street width West/East direction (m) & 7 & 18 & 50 \\
\hline Building width North/South direction (m) & 25 & 10 & 30 \\
\hline Building width West/East direction (m) & 30 & 20 & 70 \\
\hline
\end{tabular}

The BEP+BEM urban canopy parameterization is used to define three urban types: the high intensity residential (HIR) characterized by a high density of population and buildings, low 
intensity residential (LIR) where built elements are mixed with vegetation and represent 30 $80 \%$ of the area of the atmospheric grid cell, and the commercial and industrial estates (COI). In contrast to Martilli et al. (2009), roads and other transportation infrastructures are modeled through a roughness approach. High-resolution national geographic maps (IGN 2012 $B D$ topo $\left.{ }^{\circledR}\right)$ have been combined using GIS processing to specify the urban parameterization inputs (i.e. building height histogram, street-canyon equivalent geometries, street-canyon orientation, floor population density) of the three urban types suitable for European cities. The details of the settings are given in Table 8.

\section{Table 9}

Radiative, thermal, and aerodynamic properties of the construction materials (from Krpo (2009) and http://www.maison.com/architecture/maison-basse-consommation/bibliotheque-materiauxconstruction-4818/)

\begin{tabular}{|c|c|c|}
\hline Materials & Heat diffusivity & Heat capacity \\
\hline \multicolumn{3}{|c|}{ Roofs (albedo: 0.1, Emissivity: 0.9, Roughness length: 0.01) } \\
\hline$O S B$ & $0.13 * 10^{-6}$ & $982.08 * 10^{3}$ \\
\hline $\operatorname{Air}\left(1.2 \mathrm{~kg} / \mathrm{m}^{3}\right)$ & $21.75 * 10^{-6}$ & $1.20 * 10^{3}$ \\
\hline Vapor check membrane & $7,692.31 * 10^{-6}$ & $298.99 * 10^{3}$ \\
\hline Glass wool $\left(18 \mathrm{~kg} / \mathrm{m}^{3}\right)$ & $2.37 * 10^{-6}$ & $18.54 * 10^{3}$ \\
\hline AGEPAN & $1.30 * 10^{-6}$ & $58,333.00 * 10^{3}$ \\
\hline Brown tile & $0.59 * 10^{-6}$ & $655.00 * 10^{3}$ \\
\hline \multicolumn{3}{|c|}{ Walls (albedo: 0.2, Emissivity: 0.9, Roughness length: -) } \\
\hline Gypsum (BA13) & $0.30 * 10^{-6}$ & $831.60 * 10^{3}$ \\
\hline $\operatorname{Air}\left(1.2 \mathrm{~kg} / \mathrm{m}^{3}\right)$ & $21.75 * 10^{-6}$ & $1.20 * 10^{3}$ \\
\hline Glass wool $\left(18 \mathrm{~kg} / \mathrm{m}^{3}\right)$ & $2.37 * 10^{-6}$ & $18.54 * 10^{3}$ \\
\hline Standard performed bricks & $0.59 * 10^{-6}$ & $655.00 * 10^{3}$ \\
\hline Roughcast in cement & $0.49 * 10^{-6}$ & $1,642.00 * 10^{3}$ \\
\hline \multicolumn{3}{|l|}{ Undergrounds and floors } \\
\hline Concrete & $1,636.90 * 10^{-6}$ & $2,167.20 * 10^{3}$ \\
\hline Glass wool $\left(18 \mathrm{~kg} / \mathrm{m}^{3}\right)$ & $2.37 * 10^{-6}$ & $18.54 * 10^{3}$ \\
\hline $\operatorname{Air}\left(1.2 \mathrm{~kg} / \mathrm{m}^{3}\right)$ & $21.75 * 10^{-6}$ & $1.20 * 10^{3}$ \\
\hline
\end{tabular}

Two multilayered wall systems have been designed for on the one hand the COI, and on the other hand the HIR and LIR. For HIR and LIR, roof thickness is $0.16 \mathrm{~m}$, wall thickness is $0.38 \mathrm{~m}$, the floor is $0.6 \mathrm{~m}$, and the underground is $0.96 \mathrm{~m}$. Roofs are built of brown tiles and Oriented Strand Board plate; they are protected by a $9 \mathrm{~cm}$ layer of glass wool and water check membrane. Walls are made of $20 \mathrm{~cm}$ perforated standard bricks that are insulated by glass wool and two air layers. Roughcast in cement covers the outdoor layer of the walls. The floors are made of two layers of concrete material sandwiching a glass wool insulation layer. For COI, the walls are made of successive layers of gypsum, air, glass wool insulation, and concrete materials. Concrete, air, and glass wool insulation material layers compose the roofs. The thermal properties of the materials are given in Table $\mathbf{9}$.

Those settings remain unchanged for the simulations of 2030 as compared to the 2010 initial situation. 
The BEP+BEM urban model computes the space heating energy demands for each floor of a simplified standard building. For these simulations, the thermal comfort range has been fixed at $1{ }^{\circ} \mathrm{C}$ with target temperatures set to $19.85{ }^{\circ} \mathrm{C}$ for all buildings. Other parameters are the ventilation rate set to 0.75 and the windows to wall fractions set to 0.20 for COI buildings (Salamanca et al. 2012), and 0.15 for HIR and LIR. The coefficient of performance of the heat pump system has been set to 0.9 (Martilli 2014). The floor population densities were defined according to the 1999 INSEE population census data. Growth rate comes from INSEE (2007) data for the period 1999-2005. We have extrapolated constant growth over the 1999-2030 period. The population affected in each atmospheric grid cell is proportional to the building plane surfaces of the cell. The floor population density is then 6.86 individuals (ind.) per $100 \mathrm{~m}^{2}$ for HIR, 1.02 ind./100m², for LIR, and 0.31 ind./100 $\mathrm{m}^{2}$ for COI. Based on that, the compact scenario gains $+53,939$ inhabitants from 2010 to 2030 and the moderately compact scenario gains $+89,235$ inhabitants. The compact scenario corresponds well with the projections of the local development plan, which figures out $+50,000$ inhabitants by 2030 in Strasbourg Eurometropolis (CUS 2012), whose spatial extent is slightly smaller than the spatial extent of the simulated compact urban agglomeration. The number of inhabitants in the moderately compact scenario cannot be compared with the demographic projection done for Strasbourg Eurometropolis because the spatial extent of the simulated agglomeration is much larger and includes several peripheral communities.

The metabolic heat rate has been set at $80 \mathrm{~W}$, knowing that Sailor (2011) reported that a $75 \mathrm{~kg}$ man emits $75 \mathrm{~W}$ at rest and 100 to $200 \mathrm{~W}$ in extreme activity, Allen et al. (2011) considered $75 \mathrm{~W}$ at rest and $175 \mathrm{~W}$ at maximum, and Kikegawa et al. (2003) set the metabolic heat rate to $54.7 \mathrm{~W}$. Finally, the heat produced by equipment has been assumed to be at the maximum throughout the day; the peak heat equipment has been set at $36 \mathrm{~W} / \mathrm{m}^{2}$ for all urban types. In their study, Salamanca et al. (2012) considered $36 \mathrm{~W} / \mathrm{m}^{2}$ and $20 \mathrm{~W} / \mathrm{m}^{2}$ for COI and HIR-LIR, respectively. In contrast, the French national center for buildings has considered wasted heat production by building equipment of $5.7 \mathrm{~W} / \mathrm{m}^{2}$ during the day and 1.1 $\mathrm{W} / \mathrm{m}^{2}$ at night (CSTB 2012) and Bueno et al. (2011) set the wasted heat due to equipment at $5.58 \mathrm{~W} / \mathrm{m}^{2}$ for a typical Hausmannian building.

\section{Results}

\subsection{Validation of the meteorological fields (air temperature and wind speeds)}

The national meteorological institute Météo France freely provides the hourly 2-m air temperatures, 10-m wind speeds and directions for the three stations located in the simulation domain (Fig. 9). Entzheim-airport is located on the outskirts of the main urban center in the airport homogeneous flat terrain (150 m, 48 $33^{\prime} \mathrm{N}$ and $\left.7^{\circ} 38^{\prime} \mathrm{E}\right)$. Strasbourg-Botanique is located in the dense core of the Strasbourg Eurometropolis ( $139 \mathrm{~m}, 48^{\circ} 35^{\prime} \mathrm{N}$ and $\left.7^{\circ} 46^{\prime} \mathrm{E}\right)$ in the botanic gardens. La Wantzenau-SA station is located North East of the Strasbourg Eurodistrict and North of La Robertsau Rhine hardwood forest (493 ha) in a flat terrain (135 m, 48 $38^{\prime} \mathrm{N}$ and $7^{\circ} 50$ ' $\mathrm{E}$ ). 

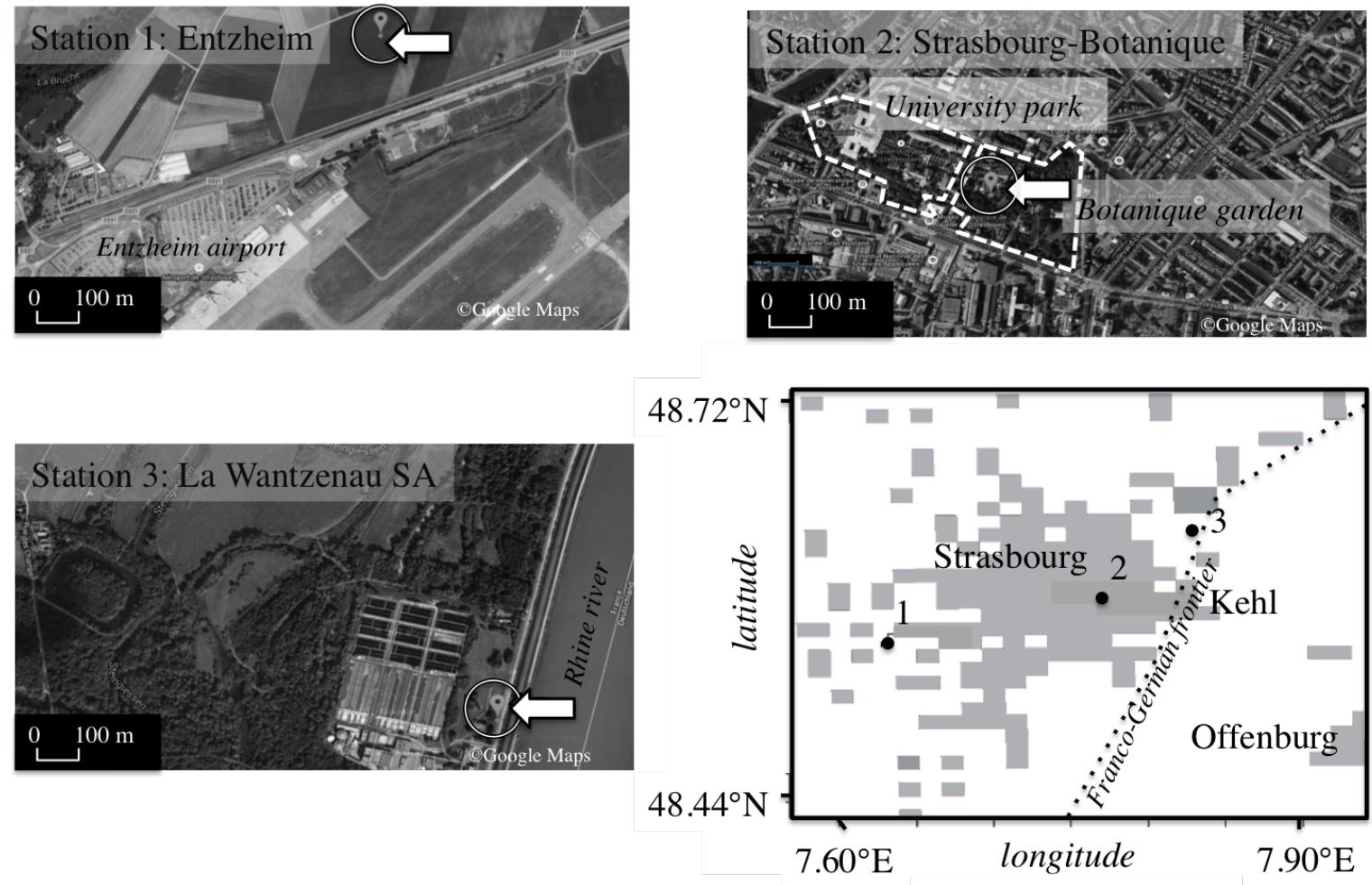

Fig. 9. Monitoring station locations and characteristics. Station 1 is Entzheim-airport. Station 2 is Strasbourg-Botanique. Station 3 is La Wantzenau. The background represents the urban area of the Strasbourg Eurodistrict as modeled in the WRF/urban climate modeling system.

Like Salamanca et al. (2011), the $1 \mathrm{~km}^{2}$ spatially averaged 2-m air temperature and 10-m wind speed simulations have been directly compared with the point-like meteorological measurements. Monthly mean biases (MBs) and root mean square errors (RMSEs) were analyzed monthly for the 2-m air temperatures (in ${ }^{\circ} \mathrm{C}$ ) (Table 10). The Pearson correlation coefficient (R) has been calculated for an annual basis. Its sensitivity is equal for all stations: 0.96 for $2-\mathrm{m}$ air temperature and around 0.60 for wind speeds. Despite the absence of a dense meteorological observation network over the domain that prevents in-depth analysis of the observed and simulated meteorological fields, the WRF/urban climate modeling system is shown to fairly reproduce the 2-m air temperature and wind speed fields. Note that the largest MBs calculated for Strasbourg-Botanique 2-m air temperature could be attributed to the cooling island effect produced by the botanical gardens (Fischer 2001). Table 10 also stresses a seasonal pattern in the MBs. The MBs are higher during the vegetative period (from March to September) at the synoptic station, and negative as compared to the other months at La Wantzenau. The RMSEs are slightly higher at Entzheim than La Wantzenau. For the wind, the MBs and the RMSE are higher at La Wantzenau with respectively $0.16 \mathrm{~m} . \mathrm{s}-1$ and 1.38 m.s-1, and 2.80 m.s- 1 and 4.82 m.s-1. Those differences can be attributed to the accuracy of the wind sensor that is lower at La Wantzenau. To extend the analysis, we have selected only moderate and strong winds ( $\mathrm{U}>2.5 \mathrm{~m} . \mathrm{s}-1)$ and then only light wind speeds $(\mathrm{U}<2.5 \mathrm{~m} . \mathrm{s}-1)$. It appears that the MBs and RMSEs increase, indicating that the WRF/urban climate model does not estimate moderate to strong winds very well. Both MBs and RMSEs decrease slightly when considering only light winds at La Wantzenau (1.33 m.s-1 and 4.10 m.s-1), but MBs increase slightly at Entzheim as compared to the RMSEs, which meantime decrease 
(0.52 m.s-1 and 2.19 m.s-1). Finally, the analysis of the simulated wind roses of the two meteorological stations indicates more frequent simulated North/North East-South/South West wind directions, especially at Entzheim. This is consistent with the channeling effect of the Rhine Graben reported by Najjar et al. (2004). It also reveals systematic eastward wind deflections as compared to the observations ranging from $0^{\circ}$ to $+45^{\circ}$.

\section{Table 10}

Statistical comparison of the observed and simulated 2-m air temperatures for 2010. MBs are monthly mean biases, and RMSEs are monthly root mean square errors.

\begin{tabular}{|l|l|l|l|l|l|l|}
\hline & \multicolumn{2}{|c|}{ Entzheim } & \multicolumn{2}{c|}{ Strasbourg-Botanique } & \multicolumn{2}{c|}{ La Wantzenau } \\
\hline (in ${ }^{\circ} \mathbf{C}$ ) & MBs & RMSEs & MBs & RMSEs & MBs & RMSEs \\
\hline January & -0.45 & 1.78 & 2.03 & 2.78 & 0.31 & 1.86 \\
\hline February & -0.47 & 1.86 & 1.79 & 2.60 & 0.15 & 1.95 \\
\hline March & -1.17 & 2.42 & 0.76 & 2.31 & -0.69 & 2.30 \\
\hline April & -1.61 & 2.73 & 0.81 & 2.40 & -1.02 & 2.45 \\
\hline May & -0.91 & 2.14 & 1.70 & 2.61 & -0.19 & 1.85 \\
\hline June & -1.25 & 2.29 & 1.90 & 2.82 & -0.44 & 1.89 \\
\hline July & -1.03 & 2.64 & 2.13 & 3.29 & -0.18 & 2.44 \\
\hline August & -0.91 & 2.28 & 2.20 & 2.99 & 0.32 & 2.00 \\
\hline September & -1.98 & 2.82 & 0.54 & 2.40 & -0.77 & 2.07 \\
\hline October & -0.28 & 2.33 & 1.59 & 2.90 & 0.84 & 2.57 \\
\hline November & -0.22 & 1.54 & 2.16 & 2.71 & 0.47 & 1.74 \\
\hline December & -0.94 & 2.23 & 2.85 & 3.53 & 1.33 & 2.38 \\
\hline
\end{tabular}

\subsection{Impacts of urban development scenarios on the urban heat island}

The urban heat island intensity, which characterizes the maximum magnitude of the UHI phenomenon, is usually defined as the difference between the rural background (i.e. the part of a city region that is not influenced by the urban heat island) and the highest urban $2 \mathrm{~m}$ air temperatures (Oke 1973).

\section{Table 11}

The urban heat island intensity for each simulated built-up pattern. In italic: the urban heat island intensities calculated according to the method of Lemonsu et al. (2015).

\begin{tabular}{|c|c|c|c|c|c|c|c|}
\hline Scenarios & $\Delta \mathrm{UHI}$ & \multicolumn{3}{|c|}{$\Delta$ UHI night } & \multicolumn{3}{|c|}{$\Delta$ UHI day } \\
\hline & Annual & Feb. & March & Sept. & Feb. & March & Sept. \\
\hline Initial case & $0.62^{\circ} \mathrm{C}$ & $\begin{array}{l}0.57^{\circ} \mathrm{C} \\
\left(1.43^{\circ} \mathrm{C}\right)\end{array}$ & $0.83^{\circ} \mathrm{C}$ & $\begin{array}{l}1.15^{\circ} \mathrm{C} \\
\left(2.84^{\circ} \mathrm{C}\right)\end{array}$ & $\begin{array}{l}0.32^{\circ} \mathrm{C} \\
\left(0.97^{\circ} \mathrm{C}\right)\end{array}$ & $0.24^{\circ} \mathrm{C}$ & $\begin{array}{l}0.37^{\circ} \mathrm{C} \\
\left(1.05^{\circ} \mathrm{C}\right)\end{array}$ \\
\hline Compact & $0.59^{\circ} \mathrm{C}$ & $\begin{array}{l}0.55^{\circ} \mathrm{C} \\
\left(1.46^{\circ} \mathrm{C}\right)\end{array}$ & $0.79^{\circ} \mathrm{C}$ & $\begin{array}{l}1.09^{\circ} \mathrm{C} \\
\left(2.84^{\circ} \mathrm{C}\right)\end{array}$ & $\begin{array}{l}0.30^{\circ} \mathrm{C} \\
\left(0.98^{\circ} \mathrm{C}\right)\end{array}$ & $0.22^{\circ} \mathrm{C}$ & $\begin{array}{l}0.33^{\circ} \mathrm{C} \\
\left(1.02^{\circ} \mathrm{C}\right)\end{array}$ \\
\hline $\begin{array}{l}\text { Moderatel } \\
\text { y compact }\end{array}$ & $0.56^{\circ} \mathrm{C}$ & $\begin{array}{l}0.52^{\circ} \mathrm{C} \\
\left(1.36^{\circ} \mathrm{C}\right)\end{array}$ & $0.77^{\circ} \mathrm{C}$ & $\begin{array}{l}1.05^{\circ} \mathrm{C} \\
\left(2.67^{\circ} \mathrm{C}\right)\end{array}$ & $\begin{array}{l}0.29^{\circ} \mathrm{C} \\
\left(0.96^{\circ} \mathrm{C}\right)\end{array}$ & $0.22^{\circ} \mathrm{C}$ & $\begin{array}{l}0.33^{\circ} \mathrm{C} \\
\left(1.02^{\circ} \mathrm{C}\right)\end{array}$ \\
\hline
\end{tabular}

Several indicators of the UHI intensities are found in the literature (Schwarz et al. 2011; Lemonsu et al., 2015). We choose here to define the UHI intensity ( $\Delta \mathrm{UHI}$ ) as the difference of the daily urban and rural simulated temperatures over the three simulated months. The daily urban (respectively rural) temperatures have been calculated as the average of the 24 
hourly $2 \mathrm{~m}$ air temperatures that composed a day of all the urban (respectively rural) atmospheric grid cells. On the same basis, we have calculated the nocturnal ( $\Delta$ UHI night) and daily ( $\Delta$ UHI day) urban heat island. The nocturnal temperatures are the average of the hourly temperatures over the 6 p.m. to 8 a.m. period of all the urban (respectively rural) grid cells of the simulation domain. The daytime temperatures are the average of the hourly temperatures over the 8 a.m. to 6 p.m. period of all the urban (respectively rural) grid cells of the domain (Table 11). Globally, this index quantifies the impacts of the urbanization on the regional climate. In addition to that, we computed another UHI intensity index by adapting the method proposed by Lemonsu et al. (2015), for the months of February and September. The rural temperature corresponds to the average temperature of a strip of four rural grid cells located at the borders of the simulation domain, assuming that these cells are very influenced by the climate conditions of the largest scales. The urban temperature corresponds to the maximum temperature of the urban grid cells located within Strasbourg city center. As compared to the former index, this index quantifies the extremes of the UHI effect and is more sensitive to the local site conditions.

With more intense UHI at night than during the day and more intense UHI in late summer than winter, the WRF/urban climate modeling system successfully reproduces the wellacknowledged diurnal and seasonal UHI patterns. As expected, the first UHI intensity index, which smooths the extremes of UHI effects, gives a lower UHI intensity than the UHI intensity index proposed by Lemonsu et al. (2015). Nevertheless, whatever the considered UHI intensity index, differences in the UHI intensities between the scenarios are negligible as shown in Table $\mathbf{1 1}$ and fall within the error ranges of the climate modeling system. The statistical distribution of daily urban temperatures for each scenario (Table 12 and Fig. 10) confirms the negligible impacts of the urban developments on daily urban temperatures.

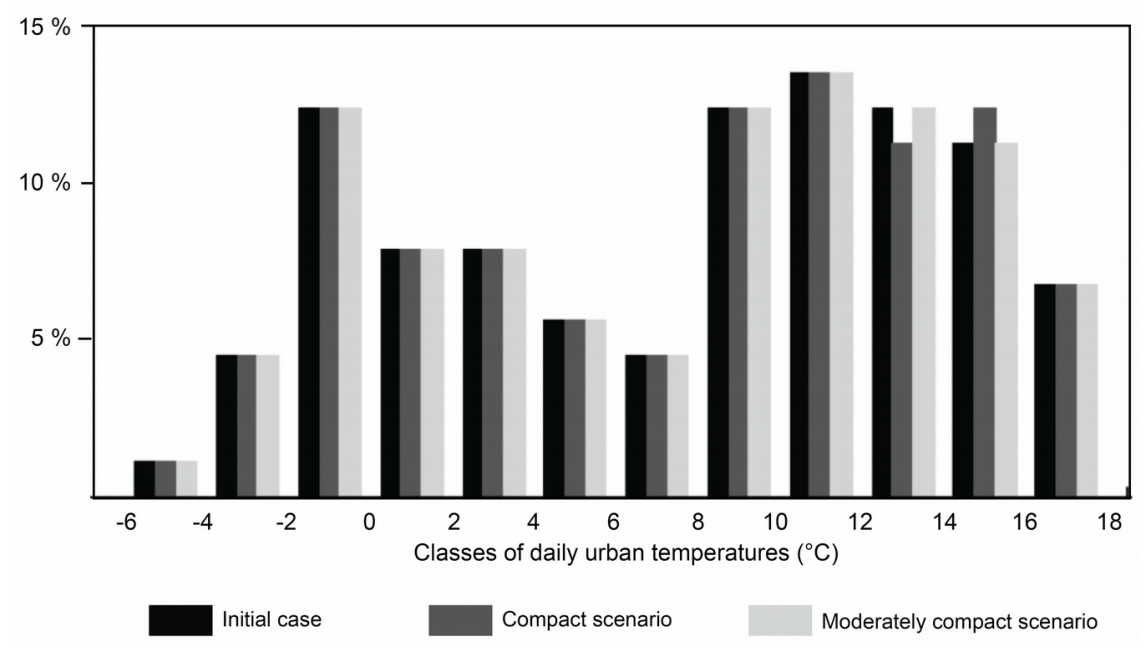

Fig. 10. Frequency distributions of the daily urban temperatures. 


\section{Table 12}

Characteristics of the statistical distributions of the daily urban temperatures.

\begin{tabular}{llll}
\hline Scenarios & Initial case & Compact & Moderately compact \\
\hline Mean $\left({ }^{\circ} \mathbf{C}\right)$ & 7.45 & 7.44 & 7.46 \\
\hline Median $\left({ }^{\circ} \mathbf{C}\right)$ & 9.09 & 9.08 & 9.04 \\
\hline Minimum $\left({ }^{\circ} \mathbf{C}\right)$ & -5.77 & -5.76 & -5.78 \\
\hline Maximum $\left({ }^{\circ} \mathbf{C}\right)$ & 17.79 & 17.92 & 17.73 \\
\hline Standard deviation $\left({ }^{\circ} \mathbf{C}\right)$ & 6.39 & 6.40 & 6.41 \\
\hline Skewness $\left({ }^{\circ} \mathbf{C}\right)$ & -0.29 & -0.30 & -0.30 \\
\hline Kurtosis $(-)$ & -1.16 & -1.15 & -1.15 \\
\hline
\end{tabular}

Spatially, the warmest surfaces in Fig. 11 (initial case) are water tables. In the main urban center, the temperatures decrease with a linear gradient of about $-0.4{ }^{\circ} \mathrm{C}$ from the warmest urban grids up to the periphery of the urban agglomeration. The greatest differences between the scenarios and the initial case are in-between $+0.7^{\circ} \mathrm{C}$ and $+0.9^{\circ} \mathrm{C}$ for the compact development scenario and $+1{ }^{\circ} \mathrm{C}$ and $+0.7^{\circ} \mathrm{C}$ for the moderately compact scenario. Pointshaped locations of warming correspond to the grid cells for which the increase in the urban fraction is greater than $20 \%$ with respect to the initial case (see Fig. 7). Yet the Pearson correlation coefficient between the urban fractions and the near-surface air temperatures is not significant ( $\mathrm{R}=0.52$ and $\mathrm{R}=0.49$ for the compact and moderately compact development scenarios, respectively) suggesting that the near-surface air temperatures are influenced more by the synoptic conditions.

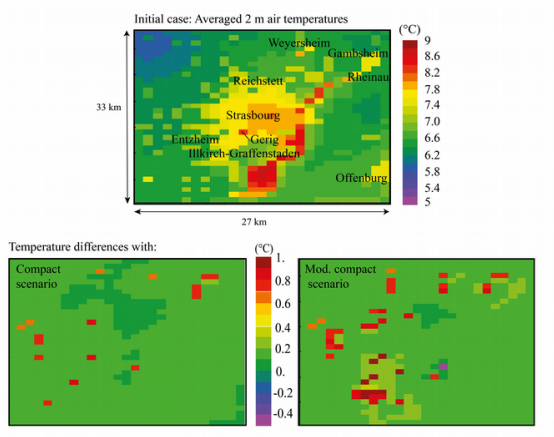

Fig. 11. Maps of the initial case's average daily air temperatures (February, March, and September) and their differences with the compact and moderately compact development scenarios (outputs from WRF/urban modeling system). 


\subsection{Impacts of urban development scenarios on space heating energy demands}

The daily building energy requirements for space heating over the simulation period (February, March, and September) have been calculated for each scenario, according to Eq. 2 and plotted as a function of the daily urban temperatures (represented by the dots in Fig. 12) to build the linear city-scale degree-day model of the housing stock of the studied zone (straight lines in Fig. 12; (for further information on the city-scale degree-day model see Kohler et al., 2016). From the linear model, we get out the urban averaged cold sensitivity $P$ and base temperatures $T_{0}$. The cold sensitivity $P$ quantifies how sensitive the buildings are to variations in the daily urban temperatures and corresponds to the slope of the function. The base temperature $T_{0}$ represents the daily urban temperature threshold at which buildings are in thermal equilibrium with their surroundings and do not consume energy for space heating (interception of the estimated straight lines with the daily outdoor temperatures axis).

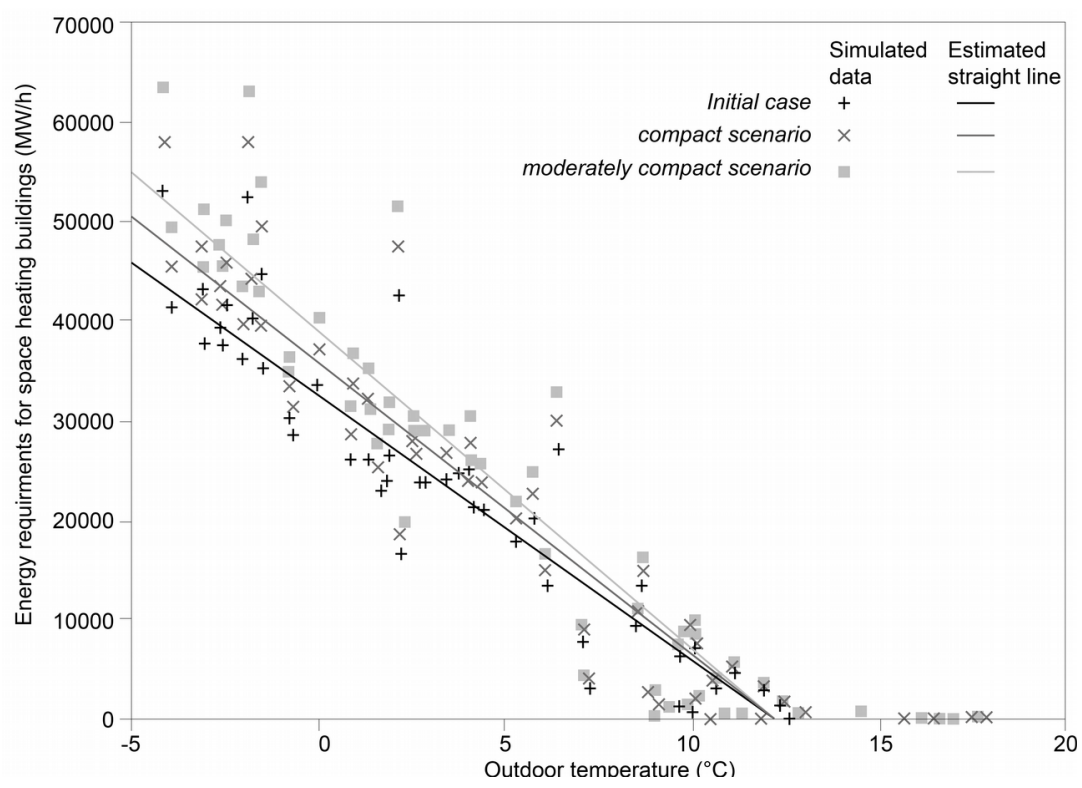

Fig. 12. Space heating energy requirements in building as a function of the daily urban temperatures (outdoor temperatures) for each scenario.

Table 13 shows that the linear model provides a good approximation of the energy requirements in buildings for space heating over the three months (with a few errors of about $3 \%$ ), and the whole year (with errors of about 5\%) for the initial case. Consequently, the three monthly simulations are judged good enough for calculating the parameters of the linear model and giving good estimations of the space heating building energy requirements over the whole year for each urban development scenario. Table 13 outlines that the cold sensitivities are more sensitive than the base temperatures to the urban development scenarios. $P$ is the highest for the moderately compact development scenario, then for the compact development scenario, and the lowest for the initial case. It also seems that the moderately compact urban form is less energy efficient than the compact urban form. However, the simple consideration of the energy requirements in buildings for space heating leads to misinterpretations: the 2010-2030 urban development area provided by the SLEUTH* simulations are not equal for the two scenarios. It is higher in the moderately compact $(1,864 \mathrm{ha})$ than the compact development scenario (1,185.24 ha). Hence, the difference in the amount of building volume to be heated between the two scenarios may 
explain the differences in space heating building energy requirements. To avoid this artifact, we have calculated the building energy requirement intensities, i.e. the space heating energy requirements in buildings related to the floor area. On this basis, we have built a second linear model for each scenario. The highest floor area is observed in the moderately compact urban development scenario $\left(68,172,584 \mathrm{~m}^{2}\right)$, then in the compact urban development scenario $\left(63,145,968 \mathrm{~m}^{2}\right)$, and the lowest in the initial case $\left(58,419,796 \mathrm{~m}^{2}\right)$. The cold sensitivities and the base temperatures secondly obtained from the linear model (Fig. 13) are relabeled $\mathrm{P}^{*}$ and $\mathrm{T}_{0}{ }^{*}$ (Table $\left.\mathbf{1 4}\right)$.

\section{Table 13}

Simulated and calculated building energy demands for space heating using the urban scale degree-day method over the three selected months (respectively, $E C_{3 m o n t h s}$ and $\left.Q_{3 m o n t h s}\right)$, the year $E C_{2010}(3,894,947$ $\mathrm{MWh}$ ), and $Q_{2010}$ respectively; and the city-scale degree-day model's parameters ( $P$, city scale building heat rate loss; $T_{0}$ city scale base temperature) for each scenario. Relative differences between simulated and calculated space heating energy demands are in (italics) and differences between the scenarios and the initial case in (regular).

\begin{tabular}{|c|c|c|c|}
\hline Scenarios & Initial case & Compact scenario & Moderately compact scenario \\
\hline \multicolumn{4}{|l|}{ Simulation results } \\
\hline EC $_{3 m o n t h s}$ (in MWh) & $1,190,334$ & $\begin{array}{l}1,382,645 \\
(+16.15 \%)\end{array}$ & $\begin{array}{l}1,506,892 \\
(+26.59 \%)\end{array}$ \\
\hline \multicolumn{4}{|l|}{ City scale degree-day model } \\
\hline$P\left(M_{W h}{ }^{\circ} \mathrm{C}^{-1}\right)$ & -2668.8 & $\begin{array}{c}-2922.6 \\
(+9.50 \%)\end{array}$ & $\begin{array}{c}-3179.2 \\
(+19.12 \%)\end{array}$ \\
\hline T0 (in ${ }^{\circ} \mathrm{C}$ ) & 12.20 & $\begin{array}{c}12.26 \\
(+0.49 \%)\end{array}$ & $\begin{array}{c}12.30 \\
(+0.81 \%)\end{array}$ \\
\hline \multicolumn{4}{|l|}{ Results of the degree-day model } \\
\hline $\mathbf{Q}_{3 \text { month }}$ (in MWh) & $1,234,227$ & $1,433,939$ & $1,563,133$ \\
\hline Q2010 (in MWh) & $4,110,100$ & $\begin{array}{r}4,534,844 \\
(+10.33 \%)\end{array}$ & $\begin{array}{r}4,957,540 \\
(+20.61 \%)\end{array}$ \\
\hline $\begin{array}{l}\text { Differences } \mathbf{Q}_{3 \text { month }}-\mathrm{EC}_{3 \mathrm{months}} \text { (in } \\
\% \text { ) }\end{array}$ & $+3.68 \%$ & $+3.70 \%$ & $+3.73 \%$ \\
\hline Differences $Q_{2010}-E_{2010}$ (in \%) & $+5.52 \%$ & & \\
\hline
\end{tabular}

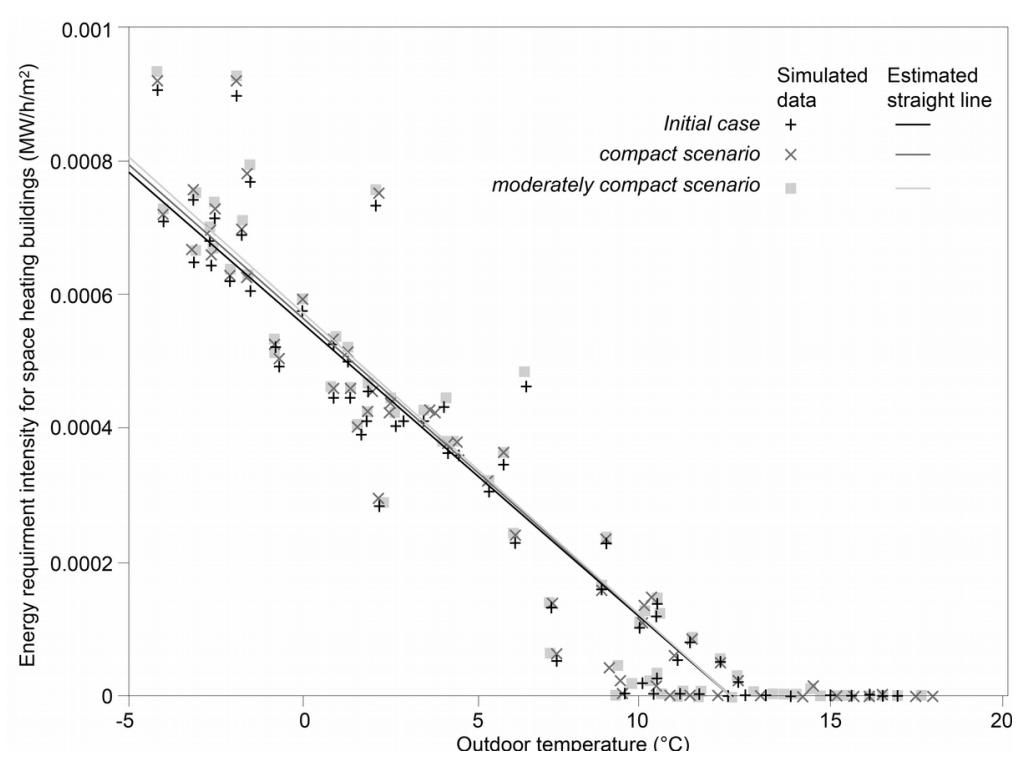


Fig. 13. Space heating energy requirement intensities in buildings as a function of the daily urban temperatures for each urban development scenario.

\section{Table 14}

Cold sensitivities $\mathrm{P}^{*}$ (in MWh. $\mathrm{C}^{-1} \cdot \mathrm{m}^{-2}$ ) and base temperatures $\mathrm{T}_{0}{ }^{*}\left({ }^{\circ} \mathrm{C}\right)$ obtained by using space heating energy intensities.

\begin{tabular}{lll}
\hline Scenarios & $\mathbf{P}^{*}$ & T0 $^{*}$ \\
\hline Initial case & $-4.57 .10^{-5}$ & 12.21 \\
\hline Compact scenario & $-4.62 .10_{-5}$ & 12.26 \\
& $(+1.08 \%)$ & $(+0.40 \%)$ \\
\hline Moderately compact scenario & $-4.66 .10^{-5}$ & 12.30 \\
& $(+1.95 \%)$ & $(+0.81 \%)$ \\
\hline
\end{tabular}

Fig. 12 and Table 14 evidence clearly very few differences between the linear models of each urban development scenario. Consequently, the differences observed in Table 13 can be attributed only to differences in the heated volume of the buildings.

\section{Discussion and conclusion}

Like previous studies (e.g. Stone and Rodgers 2001; Stone et al 2010, 2013; Tokairin et al. 2010; Aguejdad et al. 2012; Masson et al. 2014; Lemonsu et al. 2015), we have investigated how different forms of urban growth, corresponding to various levels of control of urban development and ecological planning rules (preservation of the ecological woodland habitats or no preservation), influence the urban heat island intensities and energy demands for space heating buildings. For this, we have combined off-line the SLEUTH* urban growth model with the WRF/ARW urban climate modeling system. We focused on the medium-sized Strasbourg-Kehl urban region (France-Germany) at the time horizon of 2030 that corresponds to the time horizon of the city planners.

Regarding the previous studies that, also, coupled advanced urban growth models with systems of urban climate models (Masson et al., 2014; Lemonsu et al., 2015; Alexander et al., 2016), we have, first, represented realistic and current urban development policies, like the preservation of regional ecological greens crucial for the functioning of the regional green network, in the chain of urban growth-urban climate models. Second, we have examined how contrasted macro-scale urban forms influence the urban heat island intensities and energy demands in buildings for space heating, independently from changes in the building geometry or building insulation properties.

Two additional geographical computing programs, MorphoLim and Graphab, have allowed us to implement realistic urban sprawl containment and environmental policies through the design of non-developable maps introduced as inputs in SLEUTH*. The three types of urban development simulated (compact, moderately compact, and spontaneous) produce three contrasted types of built patterns. Yet the simulated scattered built pattern could not be evaluated by the WRF/urban climate modeling system. Even by applying the $20 \%$ urban fraction threshold to assign each atmospheric grid cell to an urban or non-urban type (instead 
of the 50\% threshold proposed by default in WRF/ARW), the climate modeling system still underestimates built areas of the scattered built patterns. Therefore, we have only assessed the effect of the compact and moderately compact scenarios on the urban heat island intensity and building energy use for building heating. This limitation of the WRF/urban climate modeling system plaids for further improvements of the regional urban climate models towards finer description of the inhomogeneity of the urban surface. This purpose can be achieved by downscaling the meteorological field up to $500 \mathrm{~m}$ or $250 \mathrm{~m}$ - one challenge being the resolution of the turbulence in the models - or by coupling the regional models with the micro-scale climate/building energy models like CitySim (Allegrini et al., 2013, Mauree et al., 2015), that better account for the surface inhomogeneity and complex building geometries at the scale of neighborhoods thanks to their fine horizontal resolution.

Masson et al. (2013) and Lemonsu et al. (2015) have simulated a green belt planning strategy and a systematic and large increase of proportion of urban green cover. In contrast, we have chosen to implement an ecological rule for woodland habitat preservation. This planning rule is realistic and creates well-contrasted patterns of urbanization at a local analysis level. Yet, at a global analysis level, the simulated built patterns are quite similar with and without the ecological rule. Consequently, we have chosen not to perform simulation with the WRF/urban climate modeling system for the scenarios with the ecological rule. This may be a peculiarity of the study area, where the local planning zone and European Directives already protect large woodland areas, and where urbanization is moderately intense.

Under the compact development scenario, almost no gaps remain within built clusters. Nonetheless, the number of built clusters is higher and the area of the morphological agglomeration is smaller than under the moderately compact scenario. Thus, the simulated compact development policy generates more fragmented built patterns than the moderately compact policy. This indicates that a policy favoring compact urban development does not necessarily create connected and continuous built patterns. In particular, limiting the residential development through restrictive zoning plans favors leapfrog residential developments disconnected from existing built clusters. In contrast, the moderately compact development scenario preserves lacunae within built clusters. This scenario resembles the compact scenario of Tannier et al. (2016), which allows good preservation of ecological habitat connectivity for several forest mammal species, including the red squirrel.

New residential developments in the compact development scenario also turn out to be areas supporting the provision of short-cycle local food (i.e. family-farmed land, horticultural and greenhouse areas, brown fields, and embankments) into built-up areas, which is not wished for sustainable urban growth. Last but not least, the compact scenario achieves only $63 \%$ of the targeted urban growth. This may suggest that the road-influenced residential development rule in SLEUTH* is highly restrictive. Besides, the simulated new built areas could have corresponded to the construction of quite tall multifamily buildings in order to meet demand for new housing. However, it was not the case in our simulation with the WRF/urban climate modeling system. Actually, SLEUTH* only determines whether a grid cell is urbanized or not through the simulation. It does not specify the urban type of each new developments, their building geometry, the thermal properties, and other building characteristics (the floor 
population density, etc.). An improvement of the insulating performance of buildings (e.g. the construction of zero energy buildings) would probably lower the demand for the space heating energy. Furthermore, it would probably cool slightly the air temperatures within the city which would reduce the UHI effects, as suggested by Kohler et al. (2016).

The temperature fields seem on average to be unaffected by the simulated urban development. Significant warming locations are only observed in atmospheric grid cells for which the urban fraction threshold increases considerably (more than $20 \%$ as compared to the initial case). The local warming is slightly more pronounced in the moderately compact scenario than in the compact development scenario, in particular in areas where urban development is concentrated in several contiguous grid cells. This suggests that changes in UHI intensities and temperature fields are only observed for major changes to the built pattern. This seems not to depend on the spatial resolution of the atmospheric grid as our results are consistent with the results obtained by Aguejdad et al. (2012), who used an horizontal grid resolution of $250 \mathrm{~m}$.

In our study, UHI intensities are low compared to other studies, and frequently less than $1{ }^{\circ} \mathrm{C}$. Cantat (2004) has observed for Paris (France, 2,845 km², 10.6 million inhabitants) UHI intensities of nearly $+3{ }^{\circ} \mathrm{C}$ and $+1{ }^{\circ} \mathrm{C}$ for night and day respectively. Ketterer and Matzarakis (2014) have measured for Stuttgart (Germany, $207.36 \mathrm{~km}^{2}$, 604,297 inhabitants) an annual 2000-2011 UHI intensity of $0.3^{\circ} \mathrm{C}$ in the suburbs that could rise to $+2{ }^{\circ} \mathrm{C}$ in the city center. Finally, Hamdi and Schayes (2008) measured UHI intensities of $+5{ }^{\circ} \mathrm{C}$ at night and $+2{ }^{\circ} \mathrm{C}$ at noon in Basel from 17 to 19 June 2002 (Switzerland, $23.91 \mathrm{~km}^{2}$, 166,173 inhabitants) using one urban and one rural station. It seems that the chosen averaging procedure smooths the differential in air temperatures and explain the low UHI intensities calculated in our study.

The differences in UHI intensity between the scenarios are negligible and fall within the error ranges of the climate modeling system. This result is consistent with the literature in the field that indicates that the intensity of urbanization has little impact on UHI intensity. Seaman et al. (1989) have reported a surface temperature rise of $+0.2{ }^{\circ} \mathrm{C}$ with the tripling of the Saint Louis urban area, associated with a shift of the UHI center $6 \mathrm{~km}$ downwind and a reduction of wind convergence at the surface. Atkinson (2003) has reported an increase in the temperature by $+0.2{ }^{\circ} \mathrm{C}$ when the urban area radius of an ideal city located at $50^{\circ}$ North increases from $6 \mathrm{~km}$ to $20 \mathrm{~km}$. Tokairin et al. (2010) have found a temperature increase of about $+0.6{ }^{\circ} \mathrm{C}$ and $+0.9^{\circ} \mathrm{C}$ on average with the extension of the Jakarta urban area between the 1970s and the 2000s. According to Lemonsu et al. (2015), it is tricky to conclude on the impact of urban development policies (dense versus sprawled development) in Paris considering solely the UHI intensity indicator. They have reported differences between their two development scenarios of less than $0.2{ }^{\circ} \mathrm{C}$, and attributed these to the unchanged morphology of the historic center. Only Aguejdad et al. (2012) have found differences in the UHI intensity of $+22 \%$ and $-24 \%$ at midnight and 6 a.m. between compact and sprawled urban development scenarios for Toulouse (France, $118.30 \mathrm{~km}^{2}, 1.270$ million inhabitants), considering an urbanization intensity of 1,300 ha per year (about 1.5 times higher than the annual urbanization intensity in our study). 
Indicators of UHI intensities differ in all these studies, potentially leading to divergent results. Kastendeuch et al. (2000) proposed measuring the UHI intensity of the Strasbourg agglomeration by selecting the temperatures simulated at Place Kléber (48 $35^{\prime} 00^{\prime \prime} \mathrm{N}$ and $7^{\circ} 44^{\prime} 45^{\prime \prime} \mathrm{E}$ ) as representative of the dense urban core, and the simulated temperatures of the synoptic meteorological station of Entzheim (48³3' $\mathrm{N}$ and $7^{\circ} 38^{\prime} \mathrm{E}$ ) as representative of the rural hinterland. We applied this method to our simulated data and found an average nocturnal UHI intensity for August 2010 (between 10 p.m. and 6 a.m.) of $+3.08{ }^{\circ} \mathrm{C}$ for the initial case while Kastendeuch et al. (2000) found a nocturnal UHI intensity of $+4{ }^{\circ} \mathrm{C}$ for 1 and 2 August 2002. Nevertheless, those scholars underlined that the urban-recorded $2 \mathrm{~m}$ screen-level air temperatures reflected more specific local surface conditions inherent in the geographic location of the meteorological station or grid than the true amplitude of the UHI. Thus, it seems preferable to adopt another way to measure UHI intensity. Cantat (2004) suggested using a dense network of urban and rural meteorological stations to assess the UHI intensities of the Paris agglomeration (France, 2,845 km², 10.6 million inhabitants). Debbage and Shepherd (2015) proposed assessing UHI intensity by defining urban and rural temperatures as the average of the minimum daily temperatures of all urban grid cells of a simulation domain, and of all rural grid cells included in a 50-km radius around the built areas, respectively. Finally, Lemonsu et al. (2015) took urban temperatures to be the temperature of the atmospheric grid cells included in the city center, and rural temperatures the spatial average temperatures of all the non-urban grid cells located on the boundaries of the simulation domain. This method can provide adequate indicators when focusing on less dense urbanized zones characterized by a macrocephalic urban configuration (i.e. the existence of a single highly dominant urban pole in a urban region). The calculated rural temperature may then provide a background temperature, a fortiori because the meteorological forcing data of the parent domain are provided laterally. We have used this method to calculate the extreme UHI intensities for our scenario. We modify slightly the index by choosing the urban temperature as the maximum temperature in all the urban grid cells included in Strasbourg city center. Although UHI intensities were higher, the difference between the scenarios remains low. A similar output is obtained in the paper of Lemonsu et al. (2015), which deals with the impacts of the urban change dynamics on the urban heat island of Paris megacity by 2100 . Consequently, it is possible that the city-wide UHI saturates until a given city size, which questions the interpretation of the well-established relationship between the city size and the UHI intensity (Oke, 1984). Besides, the method of Lemonsu et al. (2015) is questionable for densely urbanized zones or national frontier zones where large secondary built centers may be located on the boundaries of the simulation domain, and modify the rural temperatures. Our research therefore suggests that further work is required to devise relevant indexes for describing the impact of development policies on the UHI effect. The UHI intensity indexes are average measurements that describe a whole study area. Temporally, such monthly averages may hide possible peaks of the UHI intensity at specific points in time; spatially, differentiations also may exist (Zhang et al., 2009; Lemonsu et al. 2015). Indeed, Figure 11 shows local increases of the air temperatures, whose value and locations are very different between the two simulated scenarios. The more numerous local increases of the air temperatures that characterize the moderately compact scenario do not impact the UHI 
intensity because the places of temperature increases are mainly located at the periphery of the urban area in 2010. The question now is whether this result could be interpreted positively in favor of a moderately compact urban development, knowing that the simulated population is higher for this scenario. Besides, the compact scenario creates numerous infilling developments in Strasbourg city center from which result no temperature increases. The key question that arises now is whether the absence of temperature increases reveals a limit of the WRF/urban climate system or a real preservation of a good ventilation of the city center that avoids local increases of the air temperatures. Actually, further researches are required to answer those questions.

Space heating energy demands are very similar for the compact and moderately compact scenarios when taking into account the differences in the area of developable land under each scenario. Simulation results suggest that the differences in heating energy demands are closely linked to the building volume to be heated but not to differences in the simulated built patterns. Nevertheless, huge uncertainty remains about the choice of the metabolic heat rate, the amount of wasted heat produced by the use of the equipment, and the temporal variation of the wasted heat produced by equipment. This may strongly influence the estimated energy demands. Besides, no differences in building form and properties were considered for the two simulated scenarios, which might have greatly changed the estimated space heating energy demands.

Finally, because many facets of the dynamics of urban systems remain unknown, it seems interesting to continue research efforts into the combination of climate modeling systems with advanced urban and ecological models, at least to better understand all factors and their interactions involved in the dynamics of those complex systems.

\section{Acknowledgments}

This study has been funded by the CNRS (ANR Trame Verte Urbaine), the European Regional Development Fund (ODIT project, MSHE CN Ledoux, Besançon, France), the ZAEU, the regional council of Alsace, and REALISE. Computations were performed on the supercomputer facilities the University of Strasbourg. Météo France, IGN, and the Strasbourg Eurométropole provided the meteorological and local geospatial databases. Special thanks are addressed to Alberto Martilli (CIEMAT, Madrid) and Jean-Christophe Foltête (ThéMA, Besançon) for their expert advice.

\section{References}

Aguejdad R., Hidalgo J., Doukari O., Masson V., and Houet T. (2012) Assessing the influence of long-term urban growth scenarios on urban climate. Proceedings of the 6th International Congress on Environmental Modeling and Software, July 1-5, 2012, at the UFZ in Leipzig, Germany. http://www.iemss.org/iemss2012/proceedings/F3_0527_Aguejdad_et_al.pdf

Alexander P., Fealy R.J., and Mills G.M. (2016) Simulating the impact of urban development pathways on the local climate: A scenario-based analysis in the greater Dublin region, Ireland. Landscape and Urban Planning. doi: http://dx.doi.org/10.1016/j.landurbplan.2016.02.006 
Allegrini J., Kämpf J., Dorer V., Carmeliet J. (2013) Modelling the urban microclimate and its influence on building energy demands of an urban neighborhood. Proceedings of CISBAT 2013 Cleantech for Smart Cities and Buildings, Lausanne (Switzerland), vol. II, p. 867-872.

Allen L., Lindberg F., and Grimmond C.S.B. (2011) Global to city scale urban anthropogenic heat flux: Model and variability. Int. J. Climatol., 31(13): 1990-2005. doi: 10.1002 :joc.2210

ASPA (2012) Méthodologie de calcul des consommations d'énergie dans le secteur résidentiel. Technical report, 2012.

Atkinson B. W. (2003) Numerical modelling of urban heat-island intensity. Boundary-Layer Meteorol., 109(3): 285-310. doi : 10.1023/A:1025820326672

Bonan G.B. (2000) The microclimates of a suburban Colorado (USA) landscape and implications for planning and design. Landscape and Urban Planning, 49(3): 97-114. doi: http://dx.doi.org/10.1016/S0169-2046(00)00071-2

Bougeault P. and Lacarrère P. (1989) Parameterization of orography-induced turbulence in a mesobeta-scale model. Mon. Weather Rev., 117(8): 1872-1890. doi : http://dx.doi.org/10.1175/15200493(1989)117<1872:POOITI >2.0.CO;2

Brazel A., Gober P., Lee S.J., Grossman-Clarke S., Zehnder J., Hedquist B., and Comparri E. (2007) Determinants of changes in the regional urban heat island in metropolitan Phoenix (Arizona, USA) between 1990 and 2004. Clim. Res., 33 (2):171-182. doi: 10.3354/cr033171

Brousse, O., Martilli, A., Foley, M., Mills, G., Bechtel, B. (2016) WUDAPT, an efficient land use producing data tool for mesoscale models? Integration of urban LCZ in WRF over Madrid. Urban Clim.

17:116-134. doi: http://dx.doi.org/10.1016/j.uclim.2016.04.001

Bueno B., Pigeon G., Norford L.K., and Zibouche K. (2011) Development and evaluation of a building energy model integrated in the TEB scheme. Geoscientific Model Development Discussions, 4(4): 2973-3011. doi: 10.5194/gmdd-4-2973-2011.

Cantat O. (2004) L'îlot de chaleur urbain parisien selon les types de temps. Norois. Environnement Aménagement Société, (191): 75-102.

Chen F. (2007) The NOAH land surface model in WRF: a short tutorial. Presentation at the LSM group meeting, April 17, 2007.

Chen F. and Dudhia J. (2001) Coupling an advanced land surface-hydrology model with the PennNcar MM5 modeling system. Part I: model implementation and sensitivity. Mon.Wea. Rev, 129: 569585. doi: http://dx.doi.org/10.1175/1520-0493(2001)129<0569:CAALSH>2.0.CO;2

Clarke K.C. (2008) A Decade of Cellular Urban Modeling with SLEUTH: Unresolved Issues and Problems, Chapter 3. In: Planning Support Systems for Cities and Regions (Ed. Brail, R. K., Lincoln Institute of Land Policy, Cambridge, http://www.ncgia.ucsb.edu/projects/gig/Pub/SLEUTHPapers Nov24/Clarke Lincoln2008.pdf

CSTB (2012) Méthode de calcul Th-BCE 2012, Technical Note: 1-1377

CUS (2012) Les orientations générales du projet d'aménagement et de développement durable. Juillet 2012. $20 \mathrm{p}$.

Debbage N. and Shepherd M. (2015) The Urban Heat Island Effect and City Contiguity. Comput. Environ. Urban Syst., 54: 181-194, doi: 10.1016/j.compenvurbsys.2015.08.002

De Munck C., Pigeon G., Masson V., Meunier F., Bousquet P., Tréméac B., Merchat M., Poeuf P., and Marchadier C. (2013) How much can air conditioning increase air temperatures for a city like Paris, France? International Journal of Climatology, 33(1): 210-227. doi: 10.1002/joc.3415.

DRIRE (2000) Energie Alsace: 2000-2020 Synthèse, $\mathrm{N}^{\circ} 16, \quad$ p.40. http://www.aurm.org/document/energie-alsace-2000-2020-synthese/show

Dudhia J. (1989) Numerical study of convection observed during the winter monsoon experiment using a mesoscale two dimensional model. Journal of Atmospheric Science, 46: 3077-3107. doi: http://dx.doi.org/10.1175/1520-0469(1989)046<3077:NSOCOD>2.0.CO;2

Emmanuel R. and Fernando H. J.S. (2007) Urban heat islands in humid and arid climates: Role of urban form and thermal properties in Colombo, Sri Lanka and Phoenix, USA. Climate Research, 34 (3): 241-251. doi: http://dx.doi.org/10.3354/cr00694 
Ewing R. and Rong F. (2008) The impact of urban form on U.S. residential energy use. Housing Policy Debate, 19(1): 1-30. doi: 10.1080/10511482.2008.9521624

Feng J., Wang Y.L., Ma Z.G., Zhu-Guo, and Y.H Liu (2012) Simulating the Regional Impacts of Urbanization and Anthropogenic Heat Release on Climate across China. American Meteorological Society, 25: 7187-7203. doi: 10.1175/JCLI-D-11-00333.1

Fischer L. (2001) Etude de paramètres climatiques pertinents en vue de l'amélioration de la prévision des pointes de pollution par l'ozone dans l'agglomération de Strasbourg. Thèse de doctorat de l’Université Louis Paster.

Foltête, J.-C., Clauzel, C., and Vuidel, G., (2012) A software tool dedicated to the modelling of landscape networks. Environ. Model. Softw. 38: 316-327. doi : 10.1016/j.envsoft.2012.07.002

Forman R. T. T. (1995) Land mosaics: the ecology of landscapes and regions. Cambridge University Press, ISBN: 9780521479806, 656 p.

Gardner R., Milne B., Turner M., and O’Neill R. (1987) Neutral models for the analysis of broadscale landscape pattern. Landscape Ecology, 1(1): 19-28.

Givoni B. (1989) Urban design in different climates. WHO technical note 346, Geneva.

Guhathakurta S. and Gober, P. (2010) Residential land use, the urban heat island, and water use in Phoenix: A path analysis. Journal of Planning Education and Research, 30(1): 40-51. doi: http://dx.doi.org/10.1177/0739456X10374187

Hagen-Zanker A. and Lajoie G. (2008) Neutral models of landscape change as benchmarks in the assessment of model performance. Landscape and Urban Planning, 86(3-4): 284-296. doi:10.1016/j.landurbplan.2008.04.002

Hamdi R. and Schayes G. (2008) Sensitivity study of the urban heat island intensity to urban characteristics. Int. J. Climatol., 28(7): 973-982. doi: 10.1002/joc.1598.

Hart M. A. and Sailor D.J. (2009) Quantifying the influence of land-use and surface characteristics on spatial variability in the urban heat island. Theoretical and Applied Climatology 95(3-4): 397-406. doi: http://dx.doi.org/10.1007/s00704-008-0017-5

Houet, T., Aguejdad, R., Doukari, O., Battaia, G., Clarke, K. (2016) Description and validation of a "non-path-dependent" model for projecting contrasting urban growth futures. Cybergeo: European Journal of Geography, 759. doi: 10.4000/cybergeo.27397

INSEE (2012) Aire urbaine de Strasbourg (partie française) (009): www.insee.fr/fr/themes/comparateur.asp?codgeo=au2010-009, last consultation: 20/03/2016

INSEE (2007) Aire urbaine de Strasbourg : une population qui augmente. Technical Report Chiffres pour l'Alsace, revue $\mathrm{N}^{\circ} 42$ : 7-10.

IUCN (2013) IUCN Red List of Threatened Species. Version 2013.1. [WWW Document]. URL www.iucnredlist.org (accessed 11.5.13).

Kastendeuch P., Lacarrere P., Najjar G., Noilhan J., Gassmann F., and P. Paul (2000). Mesoscale simulations of thermodynamic fluxes over complex terrain, Int. J. Climatol., 20(10): 1249-1264. doi: 10.1002/1097-0088(200008)20:10<1249::AID-JOC533>3.0.CO;2-U.

Ketterer C. and Matzarakis A. (2014) Comparison of different methods for the assessment of the urban heat island in Stuttgart, Germany. Int. J. Biometeorol., 59(9): 1299-309. doi: 10.1007/s00484014-0940-3

Kikegawa Y., Genchi Y., Yoshikado H., and Kondo H. (2003) Development of a numerical simulation system toward comprehensive assessments of urban warming countermeasures including their impacts upon the urban buildings' energy demands. Applied Energy, 76(4): 449 - 466. doi: 10.1016/S0306-2619(03)00009-6.

Kindelmann P., Aviron S., and Burel F. (2005) When is landscape matrix important for determining animal fluxes between resource patches? Ecological complexity, 2(2): 150-158. doi: 10.1016/j.ecocom.2004.11.007

Kohler M., Blond N., Clappier A. (2016) A city scale degree-day method to assess building space heating energy demands in Strasbourg Eurometropolis (France). Applied Energy, 184:40-54. doi: http://dx.doi.org/10.1016/j.apenergy.2016.09.075 
Kolotroni M., Ren X., Davies M., Mavrogianni A. (2012) London's urban heat island: impact of current and future energy consumption in office buildings. Energy Build., 47:302-311. doi: http://dx.doi.org/10.1016/j.enbuild.2011.12.019

Koopmans S., Theeuwes N. E., Steeneveld G. J. and Holtslag A. A. M. (2014) Modelling the influence of urbanization on the 20th century temperature record of weather station De Bilt (The Netherlands). Int. J. Climatol. 35(8): 1732-1748. doi: http://dx.doi.org/10.1002/joc.4087

Krpo A. (2009) Development and application of a numerical simulation system to evaluate the impact of anthropogenic heat fluxes on urban boundary layer climate. $\mathrm{PhD}$ thesis, Ecole Polytechnique Fédérale de Lausanne, 233 p.

Lemonsu A., Viguié V., Daniel M., and Masson V. (2015) Vulnerability to heat waves: Impact of urban expansion scenarios on urban heat island and heat stress in Paris (France). Urban Climate 14: 586-605. doi: http://dx.doi.org/10.1016/j.uclim.2015.10.007

Magli S., Lodi C., Lombroso L., Muscio A., Teggi S. (2015) Analysis of the urban heat island effects on building energy consumption. Int. J. Energy Environ Eng, 6:91-99. doi: http://dx.doi.org/10.1007/s40095-014-0154-9.

Mallampalli V.R., Mavrommati G., Thompson J., Duveneck M., Meyer S., Ligmann-Zielinska A., Gottschalk Druschke C., Hychka K., Kenney M.A., Kok K., and Borsuk M.E. (2016) Methods for translating narrative scenarios into quantitative assessments of land use change. Environ. Model. Softw. 82: 7-20. doi: http://dx.doi.org/10.1016/j.envsoft.2016.04.011

Martilli A. (2014) An idealized study of city structure, urban climate, energy consumption, and air quality. Urban Climate, 10:430-446. doi: http://dx.doi.org/10.1016/j.uclim.2014.03.003

Martilli A., Grossmann Clarke, Tewari M., and Manning K.W. (2009) Description of the modifications made in WRF.3.1 and short user's manual of BEP, technical report, 24 p. http://www.ral.ucar.edu/research/land/technology/urban/Multi_layer_UCM.pdf.

Martilli A., Clappier A., and Rotach M. W. (2002) An urban surface exchange parameterisation for mesoscale models. Boundary-Layer Meteorol., 104(2): 261-304. doi: 10.1023/A:1016099921195.

Masson V., Marchadier C., Adolphe L., Aguejdad R., Avner P., Bonhomme M., Bretagne G., Briottet X., Bueno B., De Munck C., Doukari O., Hallegatte S., Hidalgo J., Houet T., Le Bras J., Lemonsu A., Long N., Moine M.P., Morel T., Nolorgues L., Pigeon G., Salagnac JL, Viguié V., and Zibouche K. (2014) Adapting cities to climate change: a systematic modeling approach. Urban Climate, 10(2): 407-429. doi:10.1016/j.uclim.2014.03.004

Masson V., Marchadier C., Adolphe L., Aguejdad R., Avner P., Bonhomme M., Bretagne G., Briottet X., Bueno B., De Munck C., Doukari O., Hallegatte S., Hidalgo J., Houet T., Le Bras J., Lemonsu A., Long N., Moine M.P., Morel T., Nolorgues L., Pigeon G., Salagnac JL, Viguié V., and Zibouche K. (2013) Récit d'un scenario à l'horizon 2100 pour l'agglomération Toulousaine. Proceedings of the ACCLIMAT conference, 13 Décembre 2013, Toulouse.

Mauree D., Blond N., Clappier A., Kämpf J., Scartezzini J.-L. (2015) Evaluation of building energy use: from the urban to the building scale. Proceedings of the ICUC9 - 9th International Conference on Urban Climate jointly with 12th Symposium on the Urban Environment, 20-24 July Toulouse, France.

Middel A., Häb K., Brazel A.J., Martin C.A., and Guhathakurta S. (2014) Impact of urban form and design on mid-afternoon microclimate in Phoenix Local Climate Zones. Landscape and Urban Planning 122: 16-28. doi: http://dx.doi.org/10.1016/j.landurbplan.2013.11.004

Najjar G., Kastendeuch P., Stoll P., Colin J. R., Nerry F., Ringenbach N., Bernard J., De Hatten A., Ludahe R., and D. Viville (2004) Le projet reclus, Télédétection, Rayonnement et bilan d'énergie en climatologie urbaine à Strasbourg. La Météorologie, 46: 44-50. doi: 10.4267/2042/36060.

Oke T.R. (1973) City size and the urban heat island, Atmospheric Environment, 7 (8): 769-779. doi: 10.1016/0004-6981(73)90140-6

Pascual-Hortal L. and Saura S. (2007) Impact of spatial scale on the identification of critical habitat patches for the maintenance of landscape connectivity. Landsc. Urban Plan., 83(2): 176-186. doi : 10.1016/j.landurbplan.2007.04.003 
Peeters D., Caruso G., Cavailhès J., Thomas I., Frankhauser P., and Vuidel G., (2015). Emergence of leapfrogging from residential choice with endogenous green space: analytical results, Journal of Regional Science, 55(3): 491-512. doi: 10.1111/jors.12158

Pielke R.A. and Niyogi D. (2011) The role of landscape processes within the climate system. In Landform, structure, Evolution, Process Control - Lecture Notes in Earth Sciences, 115: 67-85. doi: 10.1007/978-3-540-75761-0_5

Sailor D. J. (2011). A review of methods for estimating anthropogenic heat and moisture emissions in the urban environment, Int. J. Climatol., 31(2): 189-199. doi: 10.1002/joc.2106.

Santamouris M. (2001) Energy and Climate in the Urban Built Environment. London: James and James.

Salamanca F. Martilli A., and C. Yagüe (2012) A numerical study of the urban heat island over Madrid during the Desirex (2008) campaign with WRF and an evaluation of simple mitigation strategies. Int. J. Climatol. 32(15): 2372-2386. doi: 10.1002/joc.3398

Salamanca F., Martilli A., Tewari M., and F. Chen (2011) A study of the urban boundary layer using different urban parameterizations and high-resolution urban canopy parameters with WRF, J. Appl. Meteorol. Climatol. 50(5): 1107-1128. doi: http://dx.doi.org/10.1175/2010JAMC2538.1

Salamanca F., Krpo A., Martilli A., and Clappier A. (2010) A new building energy model coupled with an urban canopy parameterization for urban climate simulations: part I. Formulation, verification, and sensitivity analysis of the model. Theor. Appl. Climatol. 99(3-4): 331-344. doi: 10.1007/s00704-009-0142-9.

Saura S. and Rubio L. (2010) A common currency for the different ways in which patches and links can contribute to habitat availability and connectivity in the landscape. Ecography 33(3): 523-537. doi : 10.1111/j.1600-0587.2009.05760.x.

Seaman N. L., Ludwig F. L., Donall E. G., Warner T., and C. M. Bhumralkar (1989) Numerical studies of urban planetary boundary-layer structure under realistic synoptic conditions. J. Appl. Meteorol. 28(8): 760-781. doi: 10.1175/1520-0450(1989)028<0760:NSOUPB>2.0.CO;2.

Shem W. and Shepherd M. (2009) On the impact of urbanization on summertime thunderstorms in Atlanta: two numerical studies, Atmospheric Research 92(2): 172-189. doi: 10.1016/j.atmosres.2008.09.013

Schwarz, N., Lautenbach, S., Seppelt, R., (2011) Exploring indicators for quantifying the surface urban heat island with MODIS land surface temperatures, Remote Sens. Environ. 115(12): 31753186. doi: 10.1016/j.rse.2011.07.003

Skamarock W. C., Klemp J. B., Dudhia J., Gill D. O., Barker D. M., Duda M., Huang X.Y., Wang W., and Powders J. G. (2008) A description of the advanced research WRF version 3. Technical report, NCAR Technical Note, NCAR/TN-475+STR. doi: 10.5065:D68S4MVH.

Stone Jr., Vargo J., Liu P., Hu Y., and A. Russell (2013), Climate change adaptation through urban heat management in Atlanta, Georgia. Environmental science \& technology 47 (14): 7780-7786. doi: 10.1021/es304352e.

Stone B., Hess J.J., and Frumkin H. (2010) Urban form and extreme heat events: are sprawling cities more vulnerable to climate change than compact cities. Environmental Health Perspectives 118(10): 1425-1428. doi: 10.1289/ehp.0901879.

Stone B. and Norman J.M. (2006) Land use planning and surface heat island formation: A parcelbased radiation flux approach. Atmospheric Environment 40: 3561-3573. doi: http://dx.doi.org/10.1016/j.atmosenv.2006.01.015

Stone Jr. and M. O. Rodgers (2001) Urban form and thermal efficiency: How the design of cities influences the urban heat island effect. Journal of the American Planning Association 67(2): 186-198. doi: 10.1080/01944360108976228.

Tannier C., Bourgeois M., Houot H., Foltête J-C. (2016) Impact of urban developments on the functional connectivity of forested habitats: a joint contribution of advanced urban models and landscape graphs, Land Use Policy, 52: 76-91. 
Tannier C., Thomas I., Vuidel G., Frankhauser P. (2011). A Fractal Approach to Identifying Urban Boundaries. Geogr. Anal. 43: 211-227.

Thompson G., Rasmussen R. M., and Manning K. (2004) Explicit forecasts of winter precipitation using an improved bulk microphysics scheme. Part I: Description and sensitivity analysis. Mon. Weather Rev. 132(2): 519-542. doi: http://dx.doi.org/10.1175/15200493(2004)132<0519:EFOWPU>2.0.CO;2.

Tokairin T., Sofyan A., and T. Kitada (2010) Effect of land use changes on local meteorological conditions in Jakarta, Indonesia: toward the evaluation of the thermal environment of megacities in Asia. Int. J. Climatol., 30(13): 1931-1941. doi: 10.1002/joc.2138.

Urban D. L., Minor E.S., Treml E. A., and R. S. Schick (2009). Graph models of habitat mosaics. Ecology letters, 12(3): 260-273. doi: 10.1111/j.1461-0248.2008.01271.x

Vogt J.A. and Oke T.R. (1998) Effects of urban surface geometry on remotely-sensed surface temperature. International Journal of Remote Sensing, 19(5): 895-920. doi: http://dx.doi.org/10.1080/014311698215784

Vyn R. J. (2012) Examining for Evidence of the Leapfrog Effect in the Context of Strict Agricultural Zoning, Land Economics, 88(3): 457-477. doi: 10.3368/le.88.3.457

Wang J., Feng J., Yan Z., Hu, Y. and Gensuo J. (2012) Nested high-resolution modeling of the impact of urbanization on regional climate in three vast urban agglomerations in China. Journal of Geophysical Research, 117:1—18. doi:10.1029/2012JD018226, 2012

Zhang N., Gao Z. Q., Wang X. M., and Chen Y. (2010) Modeling the impact of urbanization on the local and regional climate in Yangtze River Delta, China. Theor. Appl. Climatol. 102: 331-342. doi:10.1007/s00704-010-0263-1.

Zhang D.L, Shou Y.X., and Dickerson R.R. (2009) Upstream urbanization exacerbates urban heat island effects. Geophysical Research Letters, 36:1-5. doi:10.1029/2009GL041082 